Institute for Research on Poverty

Discussion Paper 1118-97

\title{
Will Extending Medicaid to Two-Parent Families Encourage Marriage?
}

\author{
Aaron S. Yelowitz \\ Department of Economics \\ University of California, Los Angeles, and NBER \\ E-mail address: yelowitz@ nber.harvard.edu
}

January 1997

I thank participants at the American Economic Association, Massachusetts Institute of Technology, National Bureau of Economic Research, the Population Association of America, RAND, and University of California, Los Angeles for helpful comments. Joshua Angrist, Janet Currie, David Cutler, Peter Diamond, Leora Friedberg, Frances Goldscheider, Jerry Hausman, Caroline Minter Hoxby, Hilary Hoynes, Wei-Yin Hu, Jacob Klerman, Lee Lillard, Steven Pischke, James Poterba, T. Paul Schultz, Anne Winkler, Duncan Thomas, two anonymous referees, and coeditor J. Karl Scholz provided helpful comments. Jonathan Gruber deserves special mention for his input. Gloria Chiang and Sheri Zwirlein provided excellent proofreading. The National Institute of Aging and the UCLA Academic Senate graciously provided financial support.

IRP publications (discussion papers, special reports, and the newsletter Focus) are now available electronically. The IRP Web Site can be accessed at the following address: http://www.ssc.wisc.edu/irp/ 


\begin{abstract}
Several welfare programs in the United States restrict eligibility to single-parent families. This paper asks whether eliminating this restriction for Medicaid encourages marriage. I identify Medicaid's effect through a series of health insurance reforms that were passed in the 1980s and 1990s targeting young children. These reforms were associated with an increase in the probability of marriage of 1.7 percentage points. While the expansions offered some incentives to become married, they also created other incentives to become divorced (known as the "independence effect"). After controlling for the outflows from marriage due to the independence effect, the estimated effect increases by 10 percent.
\end{abstract}




\section{Will Extending Medicaid to Two-Parent Families Encourage Marriage?}

\section{INTRODUCTION}

In the United States, the Medicaid program provides public health insurance for poor, eligible families. Although the program varies across states, in all instances Medicaid furnishes a basic set of subsidized health care services. ${ }^{1}$ This program has become an increasingly important part of the welfare package because medical care costs have grown far more rapidly than general inflation. ${ }^{2}$ Not only has the program grown rapidly, but the level of Medicaid expenditure currently trails only two other domestic spending programs-Medicare and Social Security. In fiscal year 1991, the total federal and state expenditure on Medicaid for Aid to Families with Dependent Children (AFDC) recipients, $\$ 21.9$ billion, exceeded the total spending on AFDC cash benefits, \$20.3 billion (U.S. House of Representatives 1993). As with some other welfare programs, eligibility for Medicaid has historically been restricted to singleparent families with children less than 18 years old. ${ }^{3}$

Many studies have examined the links between welfare eligibility rules and family structure. Even though the effects of AFDC cash benefits have been well explored, my goal is to expand the discussion by

${ }^{1}$ Traditionally, eligibility for Medicaid has been contingent on eligibility for Aid to Families with Dependent Children (AFDC); that is, one simultaneously qualifies for Medicaid and AFDC by having net income under a state's income eligibility limit. The health insurance is retained as long as the AFDC recipient earns less than the "AFDC break-even level," the point where AFDC benefits are lost. Medicaid is entirely lost once earned income goes beyond the break-even level, generating a marginal tax rate in excess of 100 percent.

${ }^{2}$ From fiscal year 1989 to 1991 , medical prices rose by 8.4 percent per year, about 71 percent faster than general inflation. Medicaid payments per beneficiary grew by 8.2 percent per year between 1985 and 1991 (U.S. House of Representatives 1993, Medicaid Source Book).

${ }^{3}$ Most notably, cash benefits under AFDC are restricted to single-parent families and families where one parent is not biologically related to the children. Two-parent families can qualify for AFDCUnemployed Parents. The Food Stamp program has no restrictions based on marital status or family structure. 
providing empirical estimates of Medicaid's effect on marriage decisions. ${ }^{4}$ Most prior studies have been unable to convincingly isolate Medicaid's effect from AFDC's effect because eligibility standards for the two programs had been highly correlated. ${ }^{5}$

I examine Medicaid's effect through a series of health insurance expansions, targeted toward children, which occurred in the 1980s and early 1990s. These expansions severed Medicaid's link to AFDC eligibility in two ways: by eliminating the requirement that a child live in a single-parent (or cohabiting) family to qualify and by increasing the income eligibility limit for Medicaid beyond the AFDC limit. I use the variation in eligibility across states and over time in the Medicaid program to identify Medicaid's effect empirically. While the state and time dimensions are quite common to recent studies in this area, the expansions also provide a true within-state comparison group by restricting new Medicaid eligibility to younger children and not older children. The data analysis uses all three dimensions to estimate Medicaid's effect.

I reach two main conclusions from the reduced-form estimates on the 1989 to 1994 March Current Population Surveys (CPS). First, the expansions significantly increased the probability of marriage. Extending Medicaid to all children in a household is associated with an increase in the probability of marriage of 1.7 percentage points. Second, the Medicaid expansions also resulted in some women becoming divorced, since the reforms raised the Medicaid income limit for children in single- parent families beyond the previous AFDC limit. By restricting the sample to women with children who live in states with high AFDC eligibility limits (and should therefore not respond to this second effect), Medicaid's

${ }^{4}$ Previous research has mainly focused on the effect of AFDC cash benefits on marital dissolution. For the most part, this work has found small, significant positive effects of AFDC benefits on female headship. See, for example, Danziger, Jakubson, Schwartz, and Smolensky (1982), Ellwood and Bane (1985), Moffitt (1990), Hoynes (1993), and Schultz (1994). Moffitt (1992) provides a summary of existing work.

${ }^{5}$ Decker (1995), who examines the initial introduction of the Medicaid program in the 1960s, is a notable exception. 
effect increases to 2.0 percentage points. In contrast to many recent studies, the economic and statistical significance of the coefficient estimates remains after including state fixed effects in the model.

The remainder of the paper is arranged as follows: Section II briefly describes the incentives that the welfare system offers for living arrangements and discusses its potential importance. It also explains in detail the recent Medicaid expansions for children. Section III presents the model and offers several predictions from the Medicaid expansions. Section IV describes construction of the data set from the CPS, and the empirical implementation. Section V reports the results. Section VI concludes.

\section{INSTITUTIONAL BACKGROUND}

\section{A. $\quad$ Background on U.S. Welfare Programs}

The U.S. welfare system offers two benefits that are largely restricted to poor single-parent families with children: cash assistance through AFDC and health insurance through Medicaid. Before recent changes, a recipient would qualify for both AFDC and Medicaid by having income under a statespecific threshold. In 1992 these thresholds ranged from 27 percent of the federal poverty level (FPL) in Alabama to 113 percent in Arizona for a family of three. ${ }^{6}$ A second distinguishing characteristic of the programs is that eligibility is related to family structure. Although the rules allow some flexibility for

${ }^{6}$ The income eligibility limit for AFDC varies depending on the recipient's work behavior. The limit is highest during the first four months of work, when the recipient faces a tax rate of 66 percent and a $\$ 30$ monthly standard deduction. She faces a 100 percent tax rate and a $\$ 30$ standard deduction for the next eight months. Finally, she faces a 100 percent tax rate and no standard deduction after twelve months of work. The limits in the text are calculated after twelve months of work while on AFDC. The variation in AFDC benefit levels has been used in previous work on family structure, including Ellwood and Bane (1985), Hutchens, Jakubson, and Schwartz (1989), Hoffman and Duncan (1988), and Duncan and Hoffman (1990). Several studies on family structure use the sum of the AFDC and Food Stamp guarantees, such as Plotnick (1983, 1990), and Lundberg and Plotnick (1995). Moffitt $(1990,1994)$ and Hoynes (1993) use the sum of the AFDC and Food Stamp guarantees along with the average Medicaid expenditure in each state. 
stepparent households and cohabitors to qualify, in practice, the vast majority of AFDC recipients are female-headed households with children under 18 present. $^{7}$

To illustrate the potential importance of losing AFDC and Medicaid, Table 1 shows the budget constraint for a mother with two children in Illinois in 1991 (several expenses are presented at the bottom of the table). The annual AFDC benefit level of $\$ 4,404$ in Illinois is near the national median, so the conclusions from this table are applicable to many other states as well. When this mother considers marrying the father, who earns $\$ 15,000$ and lacks employer-provided health insurance, the couple loses AFDC and Medicaid benefits. For a mother with two children, Medicaid is valued at $\$ 2,342$ in Illinois. ${ }^{8}$ By marrying, the couple's total income drops by $\$ 6,220$, or 29 percent of their total income. Thus, the disincentive to marry could be substantial. The loss of Medicaid benefits accounts for a significant part of the total penalty. If both children were covered by Medicaid through the eligibility expansions used in

${ }^{7}$ As recent research has shown, eligibility for AFDC does not hinge on marriage per se (Winkler, 1995; Moffitt, Reville, and Winkler, 1994, 1995). Instead, children in stepparent families can qualify for AFDC too. Another way for two-parent families (in which both parents are biologically related to the child) to qualify for Medicaid is through AFDC-UP (unemployed parent) where the principal wage earner has a substantial attachment to the labor force. AFDC-UP has very restrictive work criteria, however, and recent Medicaid expansions might eliminate any advantage to joining this program. Children in two-parent families may be eligible under either regime, but the expansions do not involve the same restrictive work criteria. See Hoynes (1996) for more discussion of the AFDC-UP program and Winkler (1995) for evidence on its effect on family structure. Since the CPS data do not have very fine living arrangement variables (i.e., it is not possible to distinguish whether an unmarried man and woman are simply roommates or partners), this likely produces measurement error in my dependent variable. In addition, subfamilies (young mothers with children who live with their parents) also qualify for AFDC and are included in the analysis. See Hutchens, Jakubson, and Schwartz (1989) for more information on subfamilies. A final avenue onto Medicaid for two-parent families is through the Medically Needy program. This program is largely restricted to those who would otherwise qualify for AFDC except that their income is too high.

${ }^{8}$ Assuming, of course, Medicaid is valued at its average expenditure. Medicaid's cash value is computed only for the AFDC population. This calculation assumes it would be equally valued by nonparticipants. 
TABLE 1

Marriage Penalties for a Mother with Two Children and Zero Earnings Living in Illinois, 1991

Mother of Two, \$0 Earnings
Marriage, Single Male

$\$ 15,000$

0

770

Earned Income Tax Credit

$\$ 4,404$

2,820

2,342

0

$(1,418)$

(210)

Federal income tax

9,566

12,134

15,480

Marriage penalty, loss of income

6,220

Percentage change $-29$

Source: U.S. House of Representatives 1993: 1257-1265.

Assumes child care expenses of zero since the mother does not work, work expenses of $\$ 300$ per year for the male ( $\$ 25$ per month for public transportation), and Social Security taxes of $\$ 1,148$ for earning $\$ 15,000$. Note that food stamps are available to married couples, which partially offsets the loss in AFDC cash benefits for two reasons: Food Stamps taxes AFDC income at 30 percent in its calculation (so a reduction of \$1.00 in AFDC income implies an increase of \$0.30 in food stamp income), and the food stamp benefits are increasing in family size. Medicaid benefit is "cashed out" at the average expenditure in the state for AFDC participants. Covering both children through Medicaid reduces the marriage penalty by $\$ 1,434$. 
this study, the penalty for marrying would decrease by $\$ 1,434$ and the decision to marry may not be so

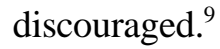

\section{B. Description of Medicaid Expansions}

To separate the effect of Medicaid from AFDC on the decision to marry, I utilize a series of health insurance expansions targeted toward children which were implemented from 1987 to 1993 . These expansions came in response to growing concern about increases in infant mortality and increases in preventable childhood diseases. ${ }^{10}$ Prior to these expansions, Medicaid eligibility was highly correlated with AFDC eligibility. The expansions severed the link to AFDC eligibility by eliminating the need for a child to live in a one-parent household in order to qualify. In addition, the Medicaid expansions usually raised the income limit to qualify, even for children in one-parent households.

The federal government first allowed and later mandated states to expand Medicaid eligibility to a broader set of children. The Omnibus Reconciliation Act of 1986 (OBRA) gave states the option to implement the expansions to children less than 2 years old up to 100 percent of the federal poverty level (FPL). OBRA 1987 gave states further options, by letting them implement expansions for children up to age 8 who were born after September 30, 1983, to 100 percent of the FPL. The new legislation also increased the income eligibility limit even more for infants. OBRA 1989 mandated coverage for children under age 6 to 133 percent of the FPL, starting in April 1990. Finally, OBRA 1990 mandated Medicaid coverage to all children under age 19 who were born after September 30, 1983, to 100 percent of the FPL.

${ }^{9}$ In Illinois, average annual Medicaid expenditure per AFDC child was $\$ 717$ in 1991 (U.S. House of Representatives 1993: 1664).

${ }^{10}$ Currie and Gruber (1994) examine the impact of related pregnancy expansions on prenatal care and infant health outcomes. 
When this phase-in is complete in the year 2002, all children living in poverty will be eligible for Medicaid. ${ }^{11}$

Table 2 illustrates the growth in Medicaid eligibility rules for children between January 1988 and December 1993. In early 1988, roughly half the states had expanded Medicaid eligibility to children under the age of 2. By the end of 1989, however, all states had implemented some form of coverage. In addition, there was a great deal of cross-sectional variation in the age limit for children, as well as some variation in the family income eligibility cutoff. As a consequence of the later federal mandates, the cross-sectional variation in the age limit disappeared by the end of 1991 — all states had expanded eligibility to children under the age of 8 . After 1991, several states used their own funding to expand eligibility to children who were not covered by the federal mandates. The states did this in two ways. First, they covered children born before October 1, 1983, who were previously excluded from these benefits. Second, they covered children living in middle-class families. For instance, Minnesota expanded Medicaid to 275 percent of the poverty line in 1993 and New York covered all children under the age of 13.

The new Medicaid rules had many consequences on health insurance coverage. First, the fraction of children eligible for Medicaid more than doubled between 1984 and 1992. By 1992, nearly one-third of all children under 18 were eligible (Currie and Gruber 1996). The expansion in eligibility also increased coverage among children. By 1991, three million children were covered from these expansions (Yelowitz 1995). Medicaid participation among all children rose by 6.7 percentage points between 1987 and 1992 , and approximately 68 percent of this rise is due to changing the eligibility rules (Shore-Sheppard 1995). The changes for children in married families were particularly dramatic. The fraction of covered children rose from 6.4 percent in 1987 to 11.8 percent in 1992 (Shore-Sheppard 1995). While part of this 84 percent increase in coverage is certainly due to covering newly eligible children in

\footnotetext{
${ }^{11}$ Appendix 1 provides a more detailed account of the law changes.
} 
TABLE 2

State Medicaid Age and Income Eligibility Thresholds for Children

\begin{tabular}{|c|c|c|c|c|c|c|c|c|}
\hline \multirow[b]{2}{*}{ State } & \multicolumn{2}{|c|}{ January 1988} & \multicolumn{2}{|c|}{ December 1989} & \multicolumn{2}{|c|}{ December 1991} & \multicolumn{2}{|c|}{ December 1993} \\
\hline & Age & Medicaid $\%$ & Age & Medicaid $\%$ & Age & Medicaid $\%$ & Age & Medicaid\% \\
\hline Alabama & & & 1 & 185 & 8 & 133 & 10 & 133 \\
\hline Alaska & & & 2 & 100 & 8 & 133 & 10 & 133 \\
\hline Arizona & 1 & 100 & 2 & 100 & 8 & 140 & 12 & 140 \\
\hline Arkansas & 2 & 75 & 7 & 100 & 8 & 185 & 10 & 133 \\
\hline California & & & 5 & 185 & 8 & 185 & 10 & 200 \\
\hline Colorado & & & 1 & 75 & 8 & 133 & 10 & 133 \\
\hline Connecticut & 0.5 & 100 & 2.5 & 185 & 8 & 185 & 10 & 185 \\
\hline Delaware & 0.5 & 100 & 2.5 & 100 & 8 & 160 & 18 & 185 \\
\hline D.C. & 1 & 100 & 2 & 100 & 8 & 185 & 10 & 185 \\
\hline Florida & 1.5 & 100 & 5 & 100 & 8 & 150 & 10 & 185 \\
\hline Georgia & 0.5 & 100 & 3 & 100 & 8 & 133 & 18 & 185 \\
\hline Hawaii & & & 4 & 100 & 8 & 185 & 10 & 185 \\
\hline Idaho & & & 1 & 75 & 8 & 133 & 10 & 133 \\
\hline Illinois & & & 1 & 100 & 8 & 133 & 10 & 133 \\
\hline Indiana & & & 3 & 100 & 8 & 150 & 10 & 150 \\
\hline Iowa & 0.5 & 100 & 5.5 & 185 & 8 & 185 & 10 & 185 \\
\hline Kansas & & & 5 & 150 & 8 & 150 & 10 & 150 \\
\hline Kentucky & 1.5 & 100 & 2 & 125 & 8 & 185 & 10 & 185 \\
\hline Louisiana & & & 6 & 100 & 8 & 133 & 10 & 133 \\
\hline Maine & & & 5 & 185 & 8 & 185 & 18 & 185 \\
\hline Maryland & 0.5 & 100 & 6 & 185 & 8 & 185 & 10 & 185 \\
\hline Massachusetts & 0.5 & 100 & 5 & 185 & 8 & 185 & 10 & 200 \\
\hline Michigan & 1 & 100 & 3 & 185 & 8 & 185 & 10 & 185 \\
\hline Minnesota & & & 6 & 185 & 8 & 185 & 18 & 275 \\
\hline Mississippi & 1.5 & 100 & 5 & 185 & 8 & 185 & 10 & 185 \\
\hline Missouri & 0.5 & 100 & 3 & 100 & 8 & 133 & 18 & 185 \\
\hline Montana & & & 1 & 100 & 8 & 133 & 10 & 133 \\
\hline Nebraska & & & 5 & 100 & 8 & 133 & 10 & 133 \\
\hline Nevada & & & 1 & 75 & 8 & 133 & 10 & 133 \\
\hline New Hampshire & & & 1 & 75 & 8 & 133 & 10 & 170 \\
\hline New Jersey & 1 & 100 & 2 & 100 & 8 & 185 & 10 & 300 \\
\hline New Mexico & 1 & 100 & 3 & 100 & 8 & 185 & 10 & 185 \\
\hline New York & & & 1 & 185 & 8 & 185 & 12 & 185 \\
\hline North Carolina & 1.5 & 100 & 7 & 100 & 8 & 185 & 10 & 185 \\
\hline North Dakota & & & 1 & 75 & 8 & 133 & 10 & 133 \\
\hline Ohio & & & 1 & 100 & 8 & 133 & 10 & 133 \\
\hline Oklahoma & 1 & 100 & 3 & 100 & 8 & 133 & 10 & 150 \\
\hline Oregon & 1.5 & 85 & 3 & 100 & 8 & 133 & 10 & 133 \\
\hline Pennsylvania & 1.5 & 100 & 6 & 100 & 8 & 133 & 10 & 185 \\
\hline
\end{tabular}


TABLE 2, continued

\begin{tabular}{|c|c|c|c|c|c|c|c|c|}
\hline \multirow[b]{2}{*}{ State } & \multicolumn{2}{|c|}{ January 1988} & \multicolumn{2}{|c|}{ December 1989} & \multicolumn{2}{|c|}{ December 1991} & \multicolumn{2}{|c|}{ December 1993} \\
\hline & Age & Medicaid\% & Age & Medicaid $\%$ & Age & Medicaid\% & Age & Medicaid $\%$ \\
\hline Rhode Island & 1.5 & 100 & 6 & 185 & 8 & 185 & 10 & 185 \\
\hline South Carolina & 1.5 & 100 & 6 & 185 & 8 & 185 & 10 & 185 \\
\hline South Dakota & & & 1 & 100 & 8 & 133 & 10 & 133 \\
\hline Tennessee & 1.5 & 100 & 6 & 100 & 8 & 185 & 10 & 185 \\
\hline Texas & & & 3 & 130 & 8 & 185 & 10 & 185 \\
\hline Utah & & & 1 & 100 & 8 & 133 & 10 & 133 \\
\hline Vermont & 1.5 & 100 & 6 & 225 & 8 & 225 & 17 & 225 \\
\hline Virginia & & & 1 & 100 & 8 & 133 & 18 & 133 \\
\hline Washington & 1.5 & 100 & 8 & 185 & 8 & 185 & 18 & 185 \\
\hline West Virginia & 0.5 & 100 & 6 & 150 & 8 & 150 & 18 & 150 \\
\hline Wisconsin & & & 1 & 130 & 8 & 155 & 10 & 155 \\
\hline Wyoming & & & 1 & 100 & 8 & 133 & 10 & 133 \\
\hline
\end{tabular}

Source: Yelowitz 1995.

Note: The age limit represents the oldest that a child could be (at a given point in time) and still be eligible. "Medicaid\%" represents the Medicaid income limit for an infant (the maximum for an older child is less). 
currently married families, it is possible that part of the increase is due to women becoming married. These trends in coverage offer promise in examining Medicaid's effect on marriage.

\section{THEORETICAL EFFECTS OF MEDICAID ON MARRIAGE}

Following Moffitt's formulation (1990), the mother compares her maximized utility in two different states of the world, married or single. Her utility function contains three arguments: a marriage indicator, leisure, and other goods. Hence the mother will marry if $\mathrm{U}\left(1, \mathrm{~L}_{1}{ }^{*}, \mathrm{OG}_{1}{ }^{*}\right)>\mathrm{U}\left(0, \mathrm{~L}_{0}{ }^{*}, \mathrm{OG}_{0}{ }^{*}\right)$. The first argument in the utility function is an indicator variable for whether the mother is married; the second $\operatorname{argument}, \mathrm{L}_{1}{ }^{*}$, is the mother's optimal quantity of leisure when married $\left(\mathrm{L}_{0}{ }^{*}\right.$ when single); and the third argument, $\mathrm{OG}_{1}{ }^{*}$, is her optimal consumption of other goods when married $\left(\mathrm{OG}_{0}{ }^{*}\right.$ when single $)$.

The bold lines in Figure 1 illustrate the budget set facing a single mother before the Medicaid expansions. The AFDC system causes the budget set for a single woman to be nonlinear. When the mother does not work, her family collects AFDC, food stamps, and Medicaid. ${ }^{12}$ As she begins to work, her AFDC and food stamp benefits are taxed away at a high rate, but she retains health insurance until she reaches the hours threshold where AFDC eligibility ends, $\mathrm{H}^{*}$. By working more than $\mathrm{H}^{*}$, her family loses Medicaid. After this point, her after-tax wage is higher (and determined through the federal and state income tax codes). The bold lines in Figure 2 illustrate the opportunities facing a married mother before the expansions. Her nonlabor income includes her husband's earnings and other transfer income, such as food stamps, which are available to two-parent families. It is further assumed that the husband does not have health insurance through his employer.

\footnotetext{
${ }^{12}$ Since the AFDC system taxes nonlabor income at 100 percent, I do not include it in Figure 1.
} 


\section{FIGURE 1}

Single Woman's Budget Set Before/After Expansion

Area $A B C D$ represents new opportunities after expansion

\section{Other Goods}

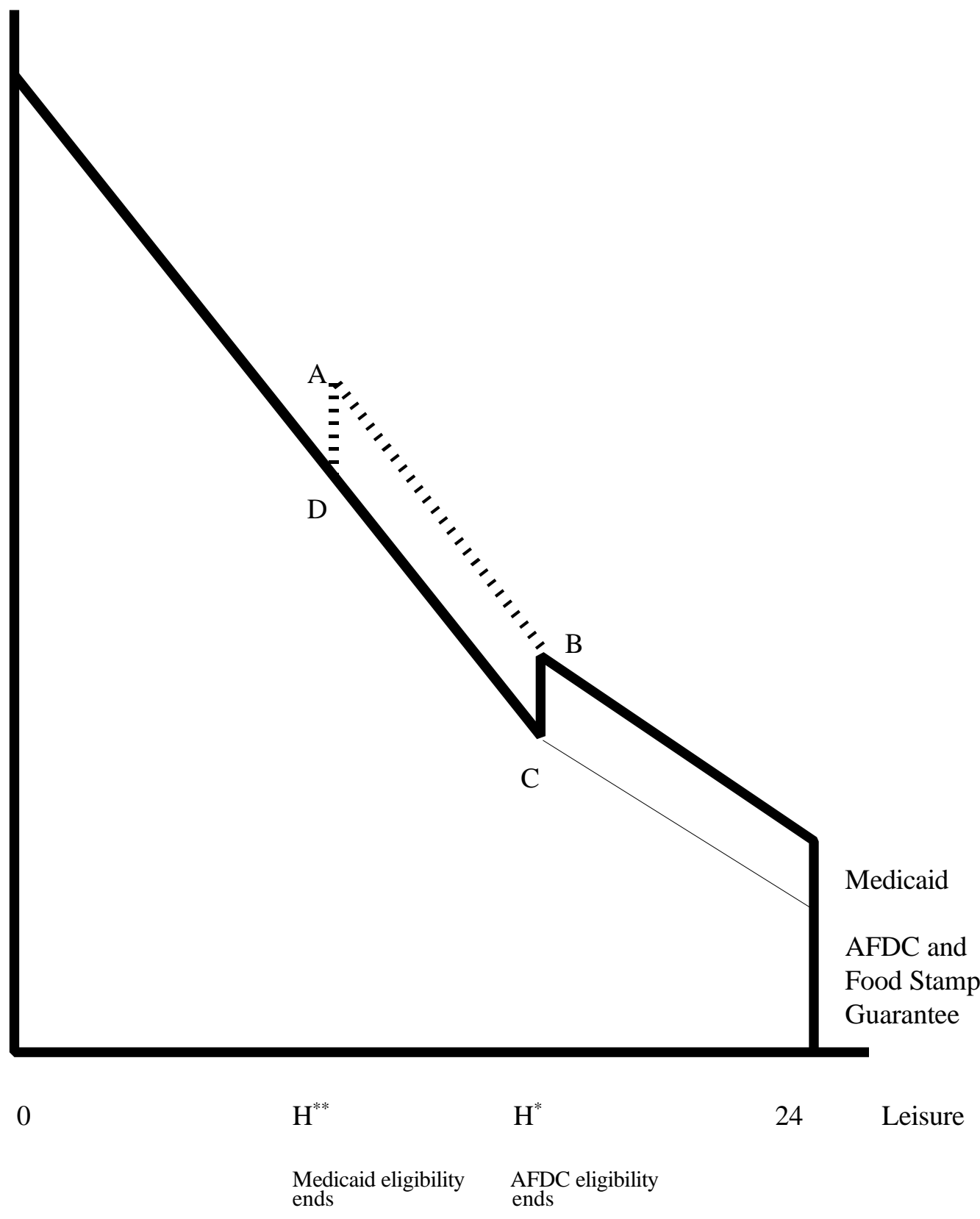


FIGURE 2

Married Woman's Budget Set Before/After Expansion

Area EFGH represents new opportunities after expansion

\section{Other Goods}

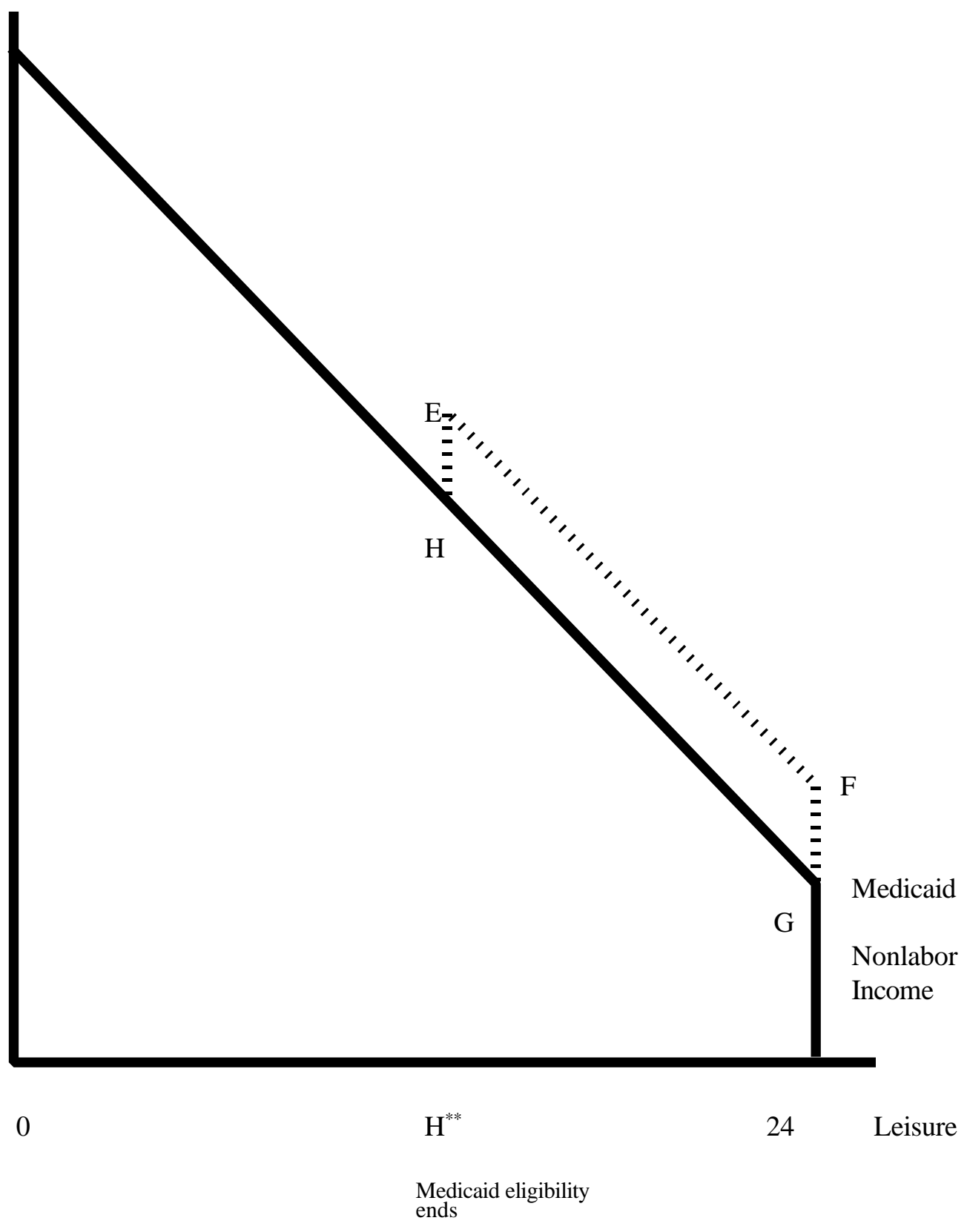


The dashed areas in the figures illustrate the effect of the Medicaid expansions on the budget sets. ${ }^{13}$ New \{Leisure, Other Goods $\}$ bundles exist for the single mother in area ABCD, and for the married mother in area EFGH. In both figures, Medicaid eligibility now ends when she works more than $\mathrm{H}^{* *} \cdot{ }^{14}$ One obvious implication from changing the budget constraints in this way is that the expansions may encourage a single mother to become married. If so, she would now locate somewhere along the line segment EF in Figure 2. Without imposing some functional form restrictions on the utility function, however, the expansions have an a priori ambiguous effect on the decision to marry. It is possible that an initially married mother would prefer to become divorced and locate at a point on the line segment AB in Figure 1. This could be construed as an "independence effect" caused by increasing the Medicaid income limit for a single mother (Groeneveld, Hannan, and Tuma 1980). ${ }^{15}$

With new bundles on both budget sets, the effect of the expansions is theoretically ambiguous. However, the design of the Medicaid expansions will allow me to infer the importance of the independence effect. Consider a Medicaid expansion that did not change the single mother's budget constraint, that is, in a state with a high AFDC income limit. ${ }^{16}$ If this is the case, then the area ABCD in Figure 1 does not exist. There are still new bundles for the married mother in Figure 2, since her family did not previously qualify for Medicaid. Because the married mother could have picked any point on the single mother's budget set

${ }^{13}$ The analysis assumes Medicaid recipients do not pay for the cost of the policy change.

${ }^{14}$ The hours threshold is identical when the woman is married or single because her market wage rate is assumed to be equal and the new Medicaid limit is the same.

${ }^{15}$ The Negative Income Tax literature also discusses the "income" effect. The idea is that income transfers help relieve financial difficulties and may therefore stabilize a shaky marriage-essentially income changes preferences. In the empirical work, I will not be able to distinguish between changes in preferences and changes in the budget constraint (in Figure 2), because I do not observe transitions to or from marriage in the CPS data. The parameter estimates should be thought of as a combination of the two effects. Since the "income effect" deals with outflows from marriage, while a change in the budget constraint deals with inflows to marriage, longitudinal data would be better suited for isolating these effects.

${ }^{16}$ The variable MEDICAID\% in Table 2 shows how the Medicaid limit varied across states and over time for infants. In some instances, this limit is less than the previous AFDC limit. 
before the expansions, she will not choose to become divorced afterward. By comparing states with high and low AFDC income limits in the empirical implementation, I will be able to isolate the flows into marriage from the Medicaid expansions. The implication from the budget constraint analysis is that the Medicaid expansions should have a stronger positive effect on marriage in high AFDC benefit states than in low AFDC benefit states.

\section{DATA DESCRIPTION AND EMPIRICAL IMPLEMENTATION}

\section{A. The Data Set}

I use repeated cross sections from the 1989 through 1994 March CPS in the analysis. I include both married and single women between the ages of 18 and 55 with at least one child younger than 15 present. ${ }^{17}$ This results in 103,159 observations where the unit of observation is the mother. To each mother's record, I linked all her children's ages. I use details on the timing and generosity of the Medicaid expansions, some of which are outlined in Table 2, to impute current Medicaid expansion eligibility. ${ }^{18}$ The expansions condition current eligibility on three exogenous margins and two endogenous margins. They create variation across states, over time, and by child's age. If a child falls into the right state-time-age

\footnotetext{
${ }^{17}$ I classify a woman as single if she is never married, divorced, separated, or widowed. I restrict the sample to households with at most ten family members, since some of the data on a state's AFDC program provides information only for families of ten or less. This is a trivial exclusion, and I retain 99.94 percent of the sample. I also include households where the woman lives in a subfamily. I use only children under age 15 because I would need to worry about their family structure decisions after that age. In addition, Table 2 shows that older teenagers were not affected by the expansions until very late in the time frame. The conclusions remain identical by using a shorter time period.

${ }^{18}$ The details of the law changes were taken from publications of the Intergovernmental Health Policy Project.

It is much more difficult to estimate how the value of Medicaid services affects marriage decisions than to estimate the effect of eligibility. Much of the variation in Medicaid services will be subsumed in the state fixed effect in the regression analysis.
} 
bracket, I classify the child as currently eligible. ${ }^{19} \mathrm{I}$ do not use the two endogenous margins, the family's income level or the mother's marital status, to compute eligibility. To make this concrete, consider the first line of Table 2, which documents the Medicaid expansions in Alabama. In 1988, all children are classified as ineligible. In 1989, I classify all children who are ages 0 and 1 as eligible for Medicaid, regardless of their family's income. Thus, children in wealthy families are classified as eligible, because I do not condition on income. In 1991, I would classify all children who are ages 8 and under as eligible for the expansions.

I then use these imputations on children to create different policy variables that reflect the new bundles on the married woman's budget set.

- $\quad$ ALLELIG is an indicator variable set equal to 1 if all the children younger than 15 in the family would be covered by the expansion if the woman became married, and 0 otherwise.

- $\quad$ ANYELIG is an indicator equal to 1 if any child in the family would be covered by the expansion if the woman became married, and 0 otherwise.

Thus, a mother in Alabama with a 3-year-old and a 9-year-old would have ALLELIG and ANYELIG set equal to 0 in both 1988 and 1989. In 1991, this mother would have ANYELIG set equal to 1, because her 3-year-old would be covered under my imputation. ALLELIG would be equal to 0 , however, because her 9-year-old is not eligible based on the state rules and time period. Finally, in 1993, both ALLELIG and ANYELIG would be equal to 1 . Therefore, ALLELIG corresponds to covering the oldest child in the family, while ANYELIG corresponds to covering the youngest child. In the entire sample, the mean of ALLELIG is 0.38 and the mean of ANYELIG is $0.55 .^{20}$

\footnotetext{
${ }^{19}$ Medicaid eligibility was evaluated as of December of the previous year. It was also necessary to impute a month and year of birth for each child, since the CPS asks only for the child's age as of March of the survey year. To impute these, I assigned a month in the year that the child could have been born based on a random draw from the empirical birth distribution of the Vital Statistics data. Since eligibility is also a function of birth year and birth month (not just child's age), I imputed eligibility this way because I did not want to systematically assign all children in a birth cohort a particular birth month.

${ }^{20}$ These measures are clearly measured with error because I do not compute eligibility based on endogenous income. This measurement error likely biases the eligibility coefficient in my model toward
} 
Table 3 presents summary statistics of the CPS variables used in the analysis. The dependent variable is marital status (asked as of March 1 of the survey year). Approximately 9 percent of the women are divorced, 5 percent are separated, 9 percent are never married, and 1 percent are widowed. Threequarters of the sample are married, but there are striking differences in marriage rates along several dimensions. First, white mothers are more than twice as likely to be married than black mothers, with a rate of 80 percent compared to 37 percent. Second, marriage rates gradually declined during the sample period, from 76.5 percent in 1989 to 72.2 percent in 1994. Third, there are differences in marital status by educational attainment and age group. Marriage rates increase until age 45, and then decline. Additionally, college-educated women are more likely to be married than other women.

The rest of the table contains independent variables that will be used in different specifications. The other explanatory variables include the mother's race, age, and educational attainment; an indicator for residence in a city; the number of children under age 6 and the number of children between ages 6 and 17. Approximately 11.6 percent of the sample are black, 4.8 percent are other nonwhite, and the remainder of the sample are white. Nearly 9 percent are Hispanic. The average age of the mothers is close to 34 years. Nearly 16 percent of these women did not finish high school, while 44 percent have some college education. ${ }^{21}$ Approximately 25 percent live in a city. The average number of children under age 6 and between ages 6 and 17 are 0.7 and 1.2, respectively. Nonlabor, nontransfer income is $\$ 2,645$ (in constant 1990 dollars). Thus, a large part of the sample is potentially on the margin for the Medicaid expansions.

zero, so the subsequent estimates may be viewed as lower bounds. Currie and Gruber (1996) discuss true changes in eligibility.

${ }^{21}$ I include dummy variables for different levels of educational attainment because the CPS changed its education variable in the middle of the sample. The classifications are: less than high school, some high school, completed high school, and any college. 
TABLE 3

CPS Summary Statistics, 1989-1994

\begin{tabular}{|c|c|c|}
\hline Variable Name & Mean & Other Comments \\
\hline Mother married (\%) & 0.744 & $\{0,1\}, 1=$ yes \\
\hline \multicolumn{3}{|l|}{ Marriage rates by demographic groups: } \\
\hline black & 0.368 & 12,019 observations \\
\hline white & 0.794 & 86,178 \\
\hline 1989 & 0.765 & 16,522 \\
\hline 1990 & 0.754 & 17,909 \\
\hline 1991 & 0.748 & 17,969 \\
\hline 1992 & 0.739 & 17,548 \\
\hline 1993 & 0.732 & 17,447 \\
\hline 1994 & 0.722 & 15,764 \\
\hline education $\leq 8$ & 0.699 & 5,429 \\
\hline $9 \leq$ education $<12$ & 0.545 & 10,372 \\
\hline education $=12$ & 0.733 & 41,753 \\
\hline education $>12$ & 0.803 & 45,605 \\
\hline $18 \leq$ age $<25$ & 0.536 & 10,617 \\
\hline $25 \leq$ age $<30$ & 0.705 & 19,117 \\
\hline $30 \leq$ age $<35$ & 0.766 & 26,641 \\
\hline $35 \leq$ age $<40$ & 0.791 & 24,532 \\
\hline $40 \leq$ age $<45$ & 0.805 & 15,103 \\
\hline $45 \leq$ age $<50$ & 0.783 & 5,578 \\
\hline $50 \leq$ age $\leq 55$ & 0.742 & 1,571 \\
\hline All children eligible for Medicaid expansion & 0.372 & $\{0,1\}, 1=$ yes \\
\hline At least one child eligible for Medicaid expansion & 0.554 & $\{0,1\}, 1=$ yes \\
\hline Black & 0.116 & $\{0,1\}, 1=$ yes \\
\hline Other nonwhite & 0.048 & $\{0,1\}, 1=$ yes \\
\hline Hispanic origin & 0.088 & $\{0,1\}, 1=$ yes \\
\hline Mother's age & 33.7 & {$[18,55]$} \\
\hline Education $\leq 8$ & 0.052 & $\{0,1\}, 1=$ yes \\
\hline $9 \leq$ Education $<12$ & 0.105 & $\{0,1\}, 1=$ yes \\
\hline Education $=12$ & 0.404 & $\{0,1\}, 1=$ yes \\
\hline Lives in central city & 0.228 & $\{0,1\}, 1=$ yes \\
\hline Number of own children ages 0 to 5 & 0.738 & {$[0,6]$} \\
\hline Number of own children ages 6 to 17 & 1.241 & {$[0,8]$} \\
\hline Nonlabor, nontransfer income & $\$ 2,645$ & Expressed in constant 1990 dollars \\
\hline
\end{tabular}

Source: Author's tabulations from the CPS, 1989-1994.

Unit of observation is mother. Number of observations is 103,159 . 


\section{B. Empirical Implementation and Identification Strategy}

I estimate a probit model to predict the effect of a child's Medicaid eligibility on the mother's decision to marry. The equation used in estimation is:

$$
\text { MARRIED }_{i}^{*}=\beta_{0}+\beta_{1} \text { ELIG }_{\mathrm{ijtk}}+\beta_{2} \mathrm{X}_{\mathrm{i}}+\sum_{\mathrm{j}} \gamma_{\mathrm{j}} \mathrm{S}_{\mathrm{j}}+\sum_{\mathrm{t}} \delta_{\mathrm{t}} \mathrm{T}_{\mathrm{t}}+\sum_{\mathrm{k}} \theta_{\mathrm{k}} \mathrm{K}_{\mathrm{k}}+\epsilon_{\mathrm{i}}
$$

where (1) is the underlying index function for the probit. MARRIED ${ }_{i}^{*}$ represents the net utility from being married. The subscript $\mathrm{i}$ indexes mothers, $\mathrm{j}$ indexes the state of residence, $\mathrm{t}$ indexes time, and $\mathrm{k}$ indexes the youngest child's age. The key independent variable, ELIG, corresponds to one of the Medicaid eligibility measures mentioned above. $X_{i}$ is a vector of exogenous individual characteristics of the mother. The variables $S_{j}, T_{t}$, and $K_{k}$ contain dummy variables for 50 states and D.C., 6 time periods, and 15 youngest child's ages, respectively.

In practice, we do not observe the underlying value for MARRIED ${ }_{i}^{*}$, but instead observe only the discrete outcome:

$$
\begin{aligned}
\text { MARRIED }_{\mathrm{i}}= & 1 \text { if } \text { MARRIED }_{\mathrm{i}}^{*} \geq 0 \\
& 0 \text { if } \operatorname{MARRIED}_{\mathrm{i}}^{*}<0 .
\end{aligned}
$$

MARRIED $_{\mathrm{i}}$ equals one if the woman is currently married and zero otherwise. Assuming that $\epsilon_{\mathrm{i}} \sim \mathrm{N}(0,1)$ and denoting $\Phi(\bullet)$ as the cumulative normal function gives the following probability:

$$
\operatorname{Prob}\left(\mathrm{MARRIED}_{\mathrm{i}}=1\right)=\Phi\left(\beta_{0}+\beta_{1} \mathrm{ELIG}_{\mathrm{ijtk}}+\beta_{2} \mathrm{X}_{\mathrm{i}}+\sum_{\mathrm{j}} \gamma_{\mathrm{j}} \mathrm{S}_{\mathrm{j}}+\sum_{\mathrm{t}} \delta_{\mathrm{t}} \mathrm{T}_{\mathrm{t}}+\sum_{\mathrm{k}} \theta_{\mathrm{k}} \mathrm{K}_{\mathrm{k}}\right)
$$

A child's eligibility for Medicaid is constructed from three arguably exogenous dimensions. It is a function of the child's age (since some children are ineligible based on being born before October 1, 1983). It is also a function of the child's state of residence (since states initially had the option of implementing the expansion), and the time period (since the expansions became more generous at the end of the period). ${ }^{22}$ By conditioning eligibility on the child's age, the expansions created differences in the budget constraint even for families within the same state at a point in time.

${ }^{22}$ Although state of residence could be endogenous because of welfare-induced migration, Walker (1994) finds no empirical evidence for this. 
The implementation of the Medicaid expansions created three comparison groups to identify the effect of extending Medicaid on marriage: mothers within a state with ineligible children, mothers across states with ineligible children, and mothers over time with ineligible children. If there are other reasons that Medicaid eligibility is correlated with the error term after conditioning on the other covariates, then the coefficient estimate on Medicaid eligibility would be biased. If attitudes toward female headship vary across states and are correlated with a state's Medicaid program but not included in the model, then the simple cross-sectional comparisons would also be biased.

By including dummy variables for STATE, TIME, and YOUNGEST child's age in the regression framework, we control for many of these omitted factors. By including state fixed effects, the effect of Medicaid is estimated from three sources of within-state variation. First, individual states changed their Medicaid program at very different rates from 1988 to 1993, either by their own choice or by federal mandate. Second, even at a point in time, Medicaid eligibility varies based on the range of ages to cover. Finally, the age distribution of children within a family (in a particular state at a point in time) provides further variation. Two families, both with a youngest child of the same age, might receive different treatment based on the ages of their older children.

Although including these first-order interactions removes many other factors that influence marriage and are correlated with eligibility, it may not remove all. The Earned Income Tax Credit (EITC), for example, offers incentives to alter living arrangements for different households (Scholz 1994). The EITC both changes over time and is more generous to families with very young children. If changes in the EITC affect marriage decisions and are correlated with more generous Medicaid eligibility, the model should include an interaction of time and child's age. ${ }^{23}$ Thus, I include interactions of state and time, and of time and child's age, in my "baseline" specification. Equation (3) is amended to be:

\footnotetext{
${ }^{23}$ The ELIG variables use variation by STATE, TIME, YOUNGEST, STATE*TIME, TIME*YOUNGEST, STATE*YOUNGEST, and STATE*TIME*YOUNGEST. Including the first-order interactions corresponds to the "differences-in-differences" estimator. Including all second-order interactions corresponds to the "differences-in-differences-in-differences" estimator.
} 


$$
\operatorname{Prob}\left(\text { MARRIED }_{\mathrm{i}}=1\right)=\Phi\left(\beta_{0}+\beta_{1} \mathrm{ELIG}_{\mathrm{ijtk}}+\beta_{2} \mathrm{X}_{\mathrm{i}}+\sum_{\mathrm{j}} \sum_{\mathrm{t}} \gamma_{\mathrm{jt}} \mathrm{S}_{\mathrm{j}} \mathrm{T}_{\mathrm{t}}+\sum_{\mathrm{t}} \sum_{\mathrm{k}} \delta_{\mathrm{tk}} \mathrm{T}_{\mathrm{t}} \mathrm{K}_{\mathrm{k}}\right)
$$

This model addresses many of the remaining concerns (for instance the changes in the EITC, which are subsumed with the TIME*YOUNGEST interaction). Finally, I estimate a model on mothers in the 25 largest states that includes all second-order interactions. By doing so, the effect of Medicaid eligibility is identified through the STATE*TIME*YOUNGEST interaction.

It is important to emphasize that the regression specification includes only a subset of variables that are thought to be important in analyzing the marriage decision. Since many of these "marriage market" variables - such as the AFDC guarantee, the market wages of men and women, the number of marriageable men, and the unemployment rate-usually vary only across states and over time in previous empirical work, the specifications that include STATE*TIME interactions should control for these factors. In addition, several individual-level variables—such as religious affiliation and family background — surely help to explain marriage rates. Unfortunately, the CPS does not provide a very rich set of individual-level variables. In any case, the key point remains the same: the goal of this paper is to provide an unbiased estimate of the effect of Medicaid eligibility on marriage decisions. By using the three dimensions outlined above, I hope to purge the Medicaid estimates of any other state- or individual-level influences.

\section{RESULTS FROM THE CPS}

\section{A. $\quad$ Basic Results}

Table 4 presents the basic results using the first measure, ALLELIG, whether or not all the children in the family were eligible. All specifications presented below include indicator variables for 
TABLE 4

Basic Results: Probit Model Predicting the Increase in Probability of Marriage

\begin{tabular}{|c|c|c|c|c|c|c|}
\hline \multirow{3}{*}{$\begin{array}{l}\text { Independent variable } \\
\text { All children eligible }\end{array}$} & \multicolumn{6}{|c|}{ Dependent Variable $=$ MARRIED } \\
\hline & \multicolumn{2}{|c|}{$(1)$} & \multicolumn{2}{|c|}{$\begin{array}{c}\text { Baseline Model } \\
\text { (2) }\end{array}$} & \multicolumn{2}{|c|}{$\begin{array}{c}25 \text { Largest States } \\
\text { (3) }\end{array}$} \\
\hline & $\begin{array}{c}.0477 \\
(.0152)\end{array}$ & $.0128 *$ & $\begin{array}{l}.0652 \\
(.0174)\end{array}$ & $.0174 *$ & $\begin{array}{l}.0549 \\
(.0192)\end{array}$ & $.0148 *$ \\
\hline Black & $\begin{array}{r}-1.0792 \\
(.0160)\end{array}$ & $-.3648 *$ & $\begin{array}{r}-1.0829 \\
(.0160)\end{array}$ & $-.3648^{*}$ & $\begin{array}{r}-1.0629 \\
(.0159)\end{array}$ & $-.3557^{*}$ \\
\hline Other nonwhite & $\begin{array}{l}-.0581 \\
(.0240)\end{array}$ & $-.0160 *$ & $\begin{array}{l}-.0577 \\
(.0241)\end{array}$ & $-.0158 *$ & $\begin{array}{l}.1502 \\
(.0296)\end{array}$ & $.0392 *$ \\
\hline Hispanic & $\begin{array}{l}-.0017 \\
(.0200)\end{array}$ & $-.0004 *$ & $\begin{array}{l}-.0001 \\
(.0201)\end{array}$ & $-.0000^{*}$ & $\begin{array}{l}.0335 \\
(.0224)\end{array}$ & $.0090 *$ \\
\hline Mother's age & $\begin{array}{c}.1761 \\
(.0056)\end{array}$ & $.0452 *$ & $\begin{array}{l}.1768 \\
(.0056)\end{array}$ & $.0452 *$ & $\begin{array}{l}.1800 \\
(.0063)\end{array}$ & $.0464 *$ \\
\hline Mother's age ${ }^{2} / 100$ & $\begin{array}{l}-.1937 \\
(.0079)\end{array}$ & $-.0555^{*}$ & $\begin{array}{l}-.1944 \\
(.0079)\end{array}$ & $-.0555^{*}$ & $\begin{array}{l}-.1988 \\
(.0090)\end{array}$ & $-.0569 *$ \\
\hline Education $<9$ & $\begin{array}{l}-.3210 \\
(.0233)\end{array}$ & $-.0941 *$ & $\begin{array}{l}-.3238 \\
(.0233)\end{array}$ & $-.0947 *$ & $\begin{array}{l}-.3480 \\
(.0247)\end{array}$ & $-.1021^{*}$ \\
\hline $9 \leq$ Education $<12$ & $\begin{array}{l}-.5159 \\
(.0169)\end{array}$ & $-.1578^{*}$ & $\begin{array}{l}-.5183 \\
(.0169)\end{array}$ & $-.1581^{*}$ & $\begin{array}{l}-.5447 \\
(.0186)\end{array}$ & $-.1664^{*}$ \\
\hline Education $=12$ & $\begin{array}{l}-.1080 \\
(.0108)\end{array}$ & $-.0294 *$ & $\begin{array}{l}-.1096 \\
(.0108)\end{array}$ & $-.0298 *$ & $\begin{array}{l}-.1408 \\
(.0125)\end{array}$ & $-.0385^{*}$ \\
\hline Central city & $\begin{array}{l}-.3087 \\
(.0126)\end{array}$ & $-.0893 *$ & $\begin{array}{l}-.3092 \\
(.0126)\end{array}$ & $-.0891^{*}$ & $\begin{array}{l}-.3391 \\
(.0129)\end{array}$ & $-.0982 *$ \\
\hline $\begin{array}{l}\text { Number of children } \\
\text { between } 0 \text { and } 5\end{array}$ & $\begin{array}{c}.1070 \\
(.0119)\end{array}$ & $.0281 *$ & $\begin{array}{l}.1083 \\
(.0119)\end{array}$ & $.0283^{*}$ & $\begin{array}{l}.0942 \\
(.0140)\end{array}$ & $.0249 *$ \\
\hline $\begin{array}{l}\text { Number of children } \\
\text { between } 6 \text { and } 17\end{array}$ & $\begin{array}{l}.1056 \\
(.0070)\end{array}$ & $.0277 *$ & $\begin{array}{c}.1094 \\
(.0071)\end{array}$ & $.0286^{*}$ & $\begin{array}{c}.1004 \\
(.0076)\end{array}$ & $.0265^{*}$ \\
\hline
\end{tabular}

(table continues) 
TABLE 4, continued

\begin{tabular}{lccc}
\hline & \multicolumn{3}{c}{ Dependent Variable = MARRIED } \\
\cline { 2 - 4 } Independent variable & $(1)$ & Baseline Model & 25 Largest States \\
\hline STATE*TIME & No & Yes
\end{tabular}

Notes: Columns each from separate regression. Estimates from CPS, 1989-1994. Huber standard errors in parentheses. Sample size is 103,159 for columns (1) and (2) and 71,803 for column (3). All specifications include STATE, TIME, and YOUNGEST child's age dummies and a constant term. All models correct for intercorrelations within each state-time-youngest cell. Probability derivatives are indicated with an asterisk in the adjacent columns. 
state, time, and the youngest child's age. ${ }^{24}$ The standard errors in all specifications are corrected for heteroscedasticity. They also correct for any residual correlations within state-time-youngest age clusters. ${ }^{25}$ Recall that the predicted effect of the eligibility expansions is ambiguous. The first two columns include the entire sample in the estimation. The first column corresponds to the "difference-in-differences" specification. The inclusion of these dummy variables controls for other factors, such as national economic conditions or fixed differences across states in attitudes toward female headship, which may be correlated with ALLELIG. The second column, which additionally controls for STATE*TIME and TIME*YOUNGEST interactions, will be called the baseline specification. By including these interactions, I control for the potential impact of AFDC cash benefits, the Medically Needy program, the EITC, and AFDC-UP on marriage separately from Medicaid's effect.

These two columns in Table 4 indicate a significant positive relationship between Medicaid and marriage. The model in column (1) shows an effect of Medicaid eligibility of 1.3 percentage points. ${ }^{26} \mathrm{I}$ am

${ }^{24}$ I have estimated the models separately for whites and African Americans, since marriage markets may look very different for these groups. In both cases, the results are similar to those reported for the pooled sample. In particular, the model that includes STATE*TIME interactions (Table 4, column 2) yielded the following results: for whites the coefficient on ALLELIG was 0.0597 (standard error of 0.0178) and the probability derivative was 0.0155 , and for African Americans the coefficient was 0.0420 (standard error of 0.0419 ) and the probability derivative was 0.0143 . Since the coefficient estimates were quite similar, I pooled the sample. It is also possible, however, that African Americans simply respond differently to Medicaid policy changes. The CPS sample size limits my ability to make strong inferences on subgroups.

${ }^{25}$ Moulton (1986) shows that ignoring these correlations may lead to the standard errors being substantially understated.

${ }^{26}$ The probability derivatives were calculated as follows. If a variable was binary, each individual's probability of marriage was calculated with the variable first equal to 1 and then equal to 0 . The difference between these predicted probabilities was then averaged across the entire sample. For continuous variables (mother's age, age squared, and number of children), the probability of marriage was calculated at the original value and that value plus 1 . The difference was again averaged across the entire sample. 
still able to precisely estimate Medicaid's effect from the within-state variation based on variation in the age distribution of children, and from the rapid changes within a state over time in Medicaid eligibility. ${ }^{27}$

While the first column eliminates many of the obvious stories that could bias the results, it is important to note that the result on Medicaid is robust to a richer set of controls. In the second column, extending Medicaid coverage to the last child in the family significantly increases the probability of marriage by 1.7 percentage points. The other variables are largely self-explanatory. Being black has a large negative impact on the probability of marriage. In contrast, the other nonwhite indicator has a much smaller negative effect. Lower levels of mother's education decrease the probability of marriage. Residing in a central city has a substantial negative impact on marriage, and the number of children (of any age group) has a substantial positive impact on the probability of marriage. As columns (1) and (2) illustrate, the coefficient estimate on ALLELIG increases with the inclusion of STATE*TIME and TIME*YOUNGEST interactions. This suggests that unmodeled factors, such as changing economic conditions within a state, may bias the estimates in column (1) downward.

The last column of Table 4 restricts the sample to the twenty-five largest states. This restriction results in 71,803 observations, or 70 percent of the original sample. This final column includes all the covariates previously included, and also includes STATE*YOUNGEST interactions. While it was not feasible to perform this "difference-in-difference-in-differences" (DDD) specification on all states, the results show that at least for these states, the estimated effect of the expansions is still positive and

\footnotetext{
${ }^{27}$ In alternate specifications, I have included the AFDC benefit for a family of four (in 1988 dollars). It should not be surprising that when both state and time effects are included, the AFDC benefit is extremely imprecisely estimated, because the impact of cash benefits on marriage is identified through changes in the guarantee within a state over time. Moffitt (1994) also finds that the correlation between female headship and real welfare benefits becomes much weaker when state-fixed effects are included. None of the conclusions about the Medicaid policy variables change by including the AFDC benefit variable, however.
} 
significant after including these additional interaction terms.$^{28}$ The point estimate falls compared to the baseline specification, however. Extending Medicaid to all children in a family leads to a 1.5 percentagepoint increase in the probability of marriage. With one exception, the other covariates remain similar to the previous columns. The exception, "other nonwhite," switches from a negative to a positive sign. This category includes several races that have different propensities to marry and differ in composition from the national sample. Hispanics, who represent a larger fraction of the population in California and Texas, might have a higher propensity to marry (or a lower propensity to divorce) through their cultural upbringing. A similar argument could be made for Asians in California. Although the model directly controls for Hispanic ethnicity, part of the effect may still come through other nonwhite.

\section{B. $\quad$ Alternative Parameterizations}

Table 5 explores a second representation of the Medicaid law: are any children in the family eligible for the Medicaid expansions? Column (1) presents estimates of ANYELIG for the model that includes both STATE*TIME and TIME*YOUNGEST interactions (corresponding to the second column of Table 4). It is likely that the result should be weaker by not necessarily covering every child in the family with Medicaid. While this intuition is borne out by the table, the results on ANYELIG are still unexpected (given the results on ALLELIG). This measure yields results that are small, negative in sign, and indistinguishable from zero.

One possible reason for the difference between the two measures could be that the effects of covering children are nonlinear. Many private or employer-provided health insurance plans offer different premiums for a single individual than for a family, but very few make a distinction based on the number of children in the family. If the mother was making the choice between purchasing private

\footnotetext{
${ }^{28}$ For the twenty-six states that I exclude, the number of observations in each state-time-youngest age cell averaged less than fourteen observations, making it too difficult to precisely estimate Medicaid's effect.
} 
TABLE 5

Alternative Parameterizations of the Medicaid Expansions

\begin{tabular}{|c|c|c|c|c|}
\hline \multirow[b]{3}{*}{ Independent variable } & \multicolumn{4}{|c|}{ Dependent Variable = MARRIED } \\
\hline & \multirow[b]{2}{*}{$(1)$} & \multirow[b]{2}{*}{$(2)$} & \multicolumn{2}{|c|}{25 Largest States } \\
\hline & & & $(3)$ & $(4)$ \\
\hline Any child eligible & $\begin{array}{l}-.0099 \\
(.0241) \\
-.0026 *\end{array}$ & --- & $\begin{array}{c}-.0266 \\
(.0325) \\
-.0072 *\end{array}$ & --- \\
\hline Oldest child eligible & --- & $\begin{array}{c}.1010 \\
(.0178) \\
.0269 *\end{array}$ & --- & $\begin{array}{l}.0877 \\
(.0209) \\
.0235^{*}\end{array}$ \\
\hline Second to oldest eligible & --- & $\begin{array}{l}-.0126 \\
(.0178) \\
-.0034 *\end{array}$ & --- & $\begin{array}{c}-.0066 \\
(.0216) \\
-.0018 *\end{array}$ \\
\hline Third to oldest eligible & --- & $\begin{array}{l}-.0168 \\
(.0278) \\
-.0045^{*}\end{array}$ & --- & $\begin{array}{c}-.0306 \\
(.0339) \\
-.0083^{*}\end{array}$ \\
\hline Fourth to oldest eligible & --- & $\begin{array}{l}-.0803 \\
(.0583) \\
-.0221 *\end{array}$ & --- & $\begin{array}{c}-.0689 \\
(.0689) \\
-.0190 *\end{array}$ \\
\hline Fifth to oldest eligible & --- & $\begin{array}{l}-.1613 \\
(.1340) \\
-.0454^{*}\end{array}$ & --- & $\begin{array}{c}-.2822 \\
(.1593) \\
-.0820 *\end{array}$ \\
\hline No second child in family & --- & $\begin{array}{l}-.2094 \\
(.0193) \\
-.0571^{*}\end{array}$ & --- & $\begin{array}{c}-.2084 \\
(.0225) \\
-.0570 *\end{array}$ \\
\hline No third child in family & --- & $\begin{array}{c}.0535 \\
(.0274) \\
.0145^{*}\end{array}$ & --- & $\begin{array}{l}.0582 \\
(.0335) \\
.0159 *\end{array}$ \\
\hline No fourth child in family & --- & $\begin{array}{c}.0850 \\
(.0546) \\
.0234^{*}\end{array}$ & --- & $\begin{array}{l}.1084 \\
(.0654) \\
.0302 *\end{array}$ \\
\hline No fifth child in family & --- & $\begin{array}{c}.0674 \\
(.1250) \\
.0185^{*} \\
\text { tinues) }\end{array}$ & --- & $\begin{array}{c}-.0404 \\
(.1493) \\
-.0108 *\end{array}$ \\
\hline
\end{tabular}


TABLE 5, continued

\begin{tabular}{|c|c|c|c|c|}
\hline \multirow[b]{3}{*}{ Independent variable } & \multicolumn{4}{|c|}{ Dependent Variable $=$ MARRIED } \\
\hline & \multirow[b]{2}{*}{$(1)$} & \multirow[b]{2}{*}{$(2)$} & \multicolumn{2}{|c|}{25 Largest States } \\
\hline & & & $(3)$ & (4) \\
\hline STATE*YOUNGEST & No & No & Yes & Yes \\
\hline Mean of dependent variable & 0.7440 & 0.7440 & 0.7326 & 0.7326 \\
\hline Pseudo $\mathrm{R}^{2}$ & .1508 & .1543 & .1640 & .1674 \\
\hline Black & $\begin{array}{r}-1.0838 \\
(.0161) \\
-.3652 *\end{array}$ & $\begin{array}{c}-1.0685 \\
(.0161) \\
-.3581 *\end{array}$ & $\begin{array}{r}-1.0637 \\
(.0159) \\
-.3560^{*}\end{array}$ & $\begin{array}{r}-1.0474 \\
(.0160) \\
-.3486^{*}\end{array}$ \\
\hline Other nonwhite & $\begin{array}{l}-.0577 \\
(.0241) \\
-.0158 *\end{array}$ & $\begin{array}{l}-.0498 \\
(.0240) \\
-.0136 *\end{array}$ & $\begin{array}{c}.1508 \\
(.0296) \\
.0394 *\end{array}$ & $\begin{array}{c}.1555 \\
(.0298) \\
.0404 *\end{array}$ \\
\hline Hispanic & $\begin{array}{l}-.0003 \\
(.0201) \\
-.0000 *\end{array}$ & $\begin{array}{c}.0052 \\
(.0203) \\
.0014 *\end{array}$ & $\begin{array}{c}.0337 \\
(.0224) \\
.0091 *\end{array}$ & $\begin{array}{c}.0371 \\
(.0225) \\
.0099 *\end{array}$ \\
\hline Mother's age & $\begin{array}{c}.1745 \\
(.0056) \\
.0446 *\end{array}$ & $\begin{array}{c}.1701 \\
(.0056) \\
.0434 *\end{array}$ & $\begin{array}{c}.1782 \\
(.0063) \\
.0459 *\end{array}$ & $\begin{array}{c}.1735 \\
(.0064) \\
.0446^{*}\end{array}$ \\
\hline Mother's age $/ 100$ & $\begin{array}{l}-.1916 \\
(.0079) \\
-.0547 *\end{array}$ & $\begin{array}{l}-.1844 \\
(.0080) \\
-.0523 *\end{array}$ & $\begin{array}{l}-.1966 \\
(.0089) \\
-.0563 *\end{array}$ & $\begin{array}{l}-.1891 \\
(.0090) \\
-.0538^{*}\end{array}$ \\
\hline Education $<9$ & $\begin{array}{l}-.3244 \\
(.0233) \\
-.0949 *\end{array}$ & $\begin{array}{l}-.3094 \\
(.0235) \\
-.0898 *\end{array}$ & $\begin{array}{l}-.3482 \\
(.0247) \\
-.1021 *\end{array}$ & $\begin{array}{l}-.3283 \\
(.0248) \\
-.0955^{*}\end{array}$ \\
\hline $9 \leq$ Education $<12$ & $\begin{array}{l}-.5206 \\
(.0169) \\
-.1588 *\end{array}$ & $\begin{array}{l}-.5078 \\
(.0169) \\
-.1538 *\end{array}$ & $\begin{array}{l}-.5463 \\
(.0186) \\
-.1670 *\end{array}$ & $\begin{array}{l}-.5318 \\
(.0186) \\
-.1614^{*}\end{array}$ \\
\hline Education $=12$ & $\begin{array}{l}-.1108 \\
(.0108) \\
-.0301 *\end{array}$ & $\begin{array}{l}-.1077 \\
(.0109) \\
-.0291 *\end{array}$ & $\begin{array}{l}-.1416 \\
(.0125) \\
-.0387 *\end{array}$ & $\begin{array}{l}-.1379 \\
(.0125) \\
-.0376^{*}\end{array}$ \\
\hline
\end{tabular}


TABLE 5, continued

\begin{tabular}{|c|c|c|c|c|}
\hline \multirow[b]{3}{*}{ Independent variable } & \multicolumn{4}{|c|}{ Dependent Variable $=$ MARRIED } \\
\hline & \multirow[b]{2}{*}{$(1)$} & \multirow[b]{2}{*}{$(2)$} & \multicolumn{2}{|c|}{ 25 Largest States } \\
\hline & & & $(3)$ & $(4)$ \\
\hline \multirow[t]{3}{*}{ Central city } & -.3090 & -.3052 & -.3390 & -.3347 \\
\hline & $(.0126)$ & $(.0126)$ & $(.0129)$ & $(.0129)$ \\
\hline & $-.0890 *$ & $-.0875^{*}$ & $-.0982 *$ & $-.0964 *$ \\
\hline \multirow{3}{*}{$\begin{array}{l}\text { Number of children } \\
\text { between } 0 \text { and } 5\end{array}$} & .1047 & .0759 & .0912 & .0674 \\
\hline & $(.0119)$ & $(.0192)$ & $(.0140)$ & $(.0230)$ \\
\hline & $.0274 *$ & $.0199 *$ & $.0241 *$ & $.0179 *$ \\
\hline \multirow{3}{*}{$\begin{array}{l}\text { Number of children } \\
\text { between } 6 \text { and } 17\end{array}$} & .0986 & .0956 & .0910 & .0883 \\
\hline & $(.0068)$ & $(.0124)$ & $(.0069)$ & $(.0144)$ \\
\hline & $.0259 *$ & $.0250 *$ & $.0241 *$ & $.0233 *$ \\
\hline STATE*YOUNGEST & No & No & Yes & Yes \\
\hline Mean of dependent variable & 0.7440 & 0.7440 & 0.7326 & 0.7326 \\
\hline Pseudo $\mathrm{R}^{2}$ & .1508 & .1543 & .1640 & .1674 \\
\hline
\end{tabular}

Notes: Columns each from separate regression. Estimates from CPS, 1989-1994. Huber standard errors in parentheses. Sample size is 103,159 for column (1), 102,771 for column (2) and 71,803 for column (3) and 71,545 for column (4). All specifications include STATE*TIME and TIME*YOUNGEST effects and a constant term. All models correct for intercorrelations within each state-time-youngest cell. Probability derivatives are marked with an asterisk. 
coverage and taking up Medicaid, then it is possible that partial Medicaid coverage for her children would be a very imperfect substitute for private coverage. To explore the difference between ALLELIG and ANYELIG further, column (2) restricts the sample to mothers with five or fewer children. This column attempts to examine where Medicaid eligibility matters by including indicator variables for whether each child in the family was covered. The variable "Oldest child eligible" refers to whether or not the oldest child in the family is Medicaid-eligible based on the state rules, time period, and child's age. The variable "Second to oldest eligible" refers to the second oldest child, and so on. Because I examine families with different numbers of children, I also include dummy variables for whether a second child was present in the family, a third child was present, and so on. The results in column (2) clearly demonstrate that covering the oldest child in a family is associated with a significant effect on marriage rates, while partial coverage has little effect. Covering the last child results in an increase in the probability of marriage of 2.4 percentage points. In contrast, the other eligibility variables are negative and insignificant. Most of the other covariates are of similar sign and significance to the first column. Although the point estimates on number of children aged between 0 and 5 and 6 and 17 are roughly the same magnitude as column (1), the standard errors rise considerably because of the inclusion of the dummy variables for presence of a second, third, fourth, and fifth child.

The third and fourth columns of Table 5 estimate the model that also includes STATE*YOUNGEST interactions, corresponding to the third column of Table 4. The results of estimating this model using the twenty-five largest states lead to the same conclusion as before: covering the last child in a family has a significant effect on marriage rates, while partial coverage has little effect. This table has shown the different estimates of the three measures and why they may differ. The remainder of the analysis 
will therefore focus on the first measure, ALLELIG, and include the same covariates as the model

presented in Table 4, column (2). ${ }^{29}$

\section{The Independence Effect}

I next examine potential outflows from marriage, due to the "independence effect." This is

motivated by previous research on the Negative Income Tax, which finds differences in divorce rates based on whether welfare benefits are awarded to the entire family unit (including the husband), or just to the wife. ${ }^{30}$ Recall that the expansions severed the link to AFDC eligibility by changing both income and family structure requirements. Since increasing the income limit could lead to new bundles on the single woman's budget set, the previous estimates could understate Medicaid's true impact (because not all of the economic incentives offered by the expansions work in the direction of becoming married).

To control for this independence effect, I restrict the sample to those women in nine high AFDCbenefit states. ${ }^{31}$ For this group of women, the Medicaid expansions should have little impact on becoming divorced. Since the expansions continued to offer new coverage for married women, they will still have an

\footnotetext{
${ }^{29}$ In addition to these eligibility measures, I have constructed a family-specific "value" of the Medicaid expansion, using the average Medicaid expenditure in the state per AFDC child and using the average health care expenditure per child from the 1987 National Medical Expenditure Survey. These two measures vary within a given state at a point in time because different families have different numbers of eligible children from the Medicaid expansions. I encountered some of the same difficulties that Blank (1989) and Winkler (1991) had-the average expenditure in Medicaid is severely measured with error, which likely biases the coefficient estimates toward zero. In all specifications, the values had a positive effect on becoming married, but were always insignificant. Since the CPS does not have good health measures, I was not able to construct an individual "value" along the lines of Moffitt and Wolfe (1992).

${ }^{30}$ See Cain and Wissoker (1990) and Hannan and Tuma (1990) for pertinent discussions.

${ }^{31}$ I selected the nine states (excluding Alaska and Hawaii) that had an AFDC benefit of at least \$500 per month for a family of three in January 1988 (U.S. House of Representatives 1988: 416-417). These states were: California, Connecticut, Massachusetts, Michigan, Minnesota, New York, Rhode Island, Vermont, and Wisconsin. I also selected nine low-benefit states that had an AFDC benefit of less than \$250. These were Alabama, Arkansas, Kentucky, Louisiana, Mississippi, South Carolina, Tennessee, Texas, and West Virginia. After the appropriate institutional detail is accounted for, such as the " 30 and 1/3 disregard," child care expenses, and work expenses, the AFDC limit can exceed the new Medicaid limit. Yelowitz (1995) discusses this detail.
} 
impact on the decision to marry. Restricting the sample leads to 28,274 observations from high-benefit states. As a contrast, I also select 16,842 observations from nine low-benefit states where the effects of the Medicaid expansion could result in higher divorce rates by dramatically changing the single woman's budget set.

Columns (1) and (2) of Table 6 show the importance of the independence effect to the coefficient estimates. The first column restricts the sample to high-benefit states. The estimated marginal effect of ALLELIG increases to 2.0 percentage points, or around 10 percent higher than the baseline estimate in Table 4. The second column shows that the estimated positive effect on marriage is somewhat lower for the low-benefit states relative to the baseline estimate. This lower estimate should be expected, because a Medicaid expansion that increases the benefit of becoming single will likely result in more divorces. While these findings show that these outflows are important, the importance of the independence effect is smaller than in the findings of Groeneveld, Hannan, and Tuma (1980).

\section{Specification Checks}

Several other checks were performed on the plausibility of the results. First, I address the robustness by examining a woman's insurance status. The Medicaid expansions should have little effect on a woman if she has health insurance through a private source. While the choice to purchase private insurance could be a function of public health insurance availability, looking at it may still provide further confidence on the basic results. ${ }^{32}$ We should expect to observe a larger effect of Medicaid by excluding women with private coverage. Approximately two-thirds of the mothers had a source of private

\footnotetext{
${ }^{32}$ The extent to which Medicaid is a substitute for other forms of coverage is controversial. Cutler and Gruber (1996) find significant crowd-out effects of public insurance, but Shore-Sheppard (1995) does not.
} 
TABLE 6

Effect of Medicaid Expansions on Different Demographic Groups

(1)

(2)

(3)

(4)

Without

High AFDC- Low AFDC With Private Private

Benefit States Benefit States Insurance
(5)

(6)

Mother Age Exclude Insurance 30 and Above Infants

\begin{tabular}{|c|c|c|c|c|c|c|}
\hline All children eligible & $\begin{array}{c}.0733 \\
(.0343) \\
.0204 *\end{array}$ & $\begin{array}{c}.0545 \\
(.0410) \\
.0149 *\end{array}$ & $\begin{array}{c}.0039 \\
(.0243) \\
.0007^{*}\end{array}$ & $\begin{array}{c}.0968 \\
(.0253) \\
.0343^{*}\end{array}$ & $\begin{array}{c}.0606 \\
(.0216) \\
.0164 *\end{array}$ & $\begin{array}{c}.0405 \\
(.0185) \\
.0112 *\end{array}$ \\
\hline Black & $\begin{array}{l}-.9388 \\
(.0337) \\
-.3157 *\end{array}$ & $\begin{array}{r}-1.1958 \\
(.0294) \\
-.4101 *\end{array}$ & $\begin{array}{l}-.9821 \\
(.0219) \\
-.2698 *\end{array}$ & $\begin{array}{l}-.9719 \\
(.0256) \\
-.3372 *\end{array}$ & $\begin{array}{r}-1.0222 \\
(.0190) \\
-.3443^{*}\end{array}$ & $\begin{array}{r}-1.0534 \\
(.0166) \\
-.3579 *\end{array}$ \\
\hline Other nonwhite & $\begin{array}{c}.2060 \\
(.0385) \\
.0550 *\end{array}$ & $\begin{array}{l}-.0886 \\
(.0918) \\
-.0250 *\end{array}$ & $\begin{array}{c}.0190 \\
(.0351) \\
.0037 *\end{array}$ & $\begin{array}{c}.0399 \\
(.0339) \\
.0141^{*}\end{array}$ & $\begin{array}{c}.0289 \\
(.0291) \\
.0078 *\end{array}$ & $\begin{array}{l}-.0423 \\
(.0251) \\
-.0119 *\end{array}$ \\
\hline Hispanic & $\begin{array}{c}.0789 \\
(.0327) \\
.0218 *\end{array}$ & $\begin{array}{l}-.1604 \\
(.0384) \\
-.0453 *\end{array}$ & $\begin{array}{l}-.1211 \\
(.0310) \\
-.0252 *\end{array}$ & $\begin{array}{c}.1287 \\
(.0277) \\
.0455^{*}\end{array}$ & $\begin{array}{l}-.0960 \\
(.0259) \\
-.0267^{*}\end{array}$ & $\begin{array}{l}-.0062 \\
(.0217) \\
-.0017 *\end{array}$ \\
\hline Mother's age & $\begin{array}{c}.1887 \\
(.0115) \\
.0502 *\end{array}$ & $\begin{array}{c}.1486 \\
(.0131) \\
.0391 *\end{array}$ & $\begin{array}{c}.0929 \\
(.0087) \\
.0177 *\end{array}$ & $\begin{array}{c}.1080 \\
(.0080) \\
.0381^{*}\end{array}$ & $\begin{array}{c}.1217 \\
(.0137) \\
.0318 *\end{array}$ & $\begin{array}{c}.1741 \\
(.0062) \\
.0462 *\end{array}$ \\
\hline Mother's age ${ }^{2} / 100$ & $\begin{array}{l}-.2068 \\
(.0161) \\
-.0612 *\end{array}$ & $\begin{array}{l}-.1651 \\
(.0189) \\
-.0475^{*}\end{array}$ & $\begin{array}{l}-.0894 \\
(.0120) \\
-.0185 *\end{array}$ & $\begin{array}{l}-.1142 \\
(.0116) \\
-.0407 *\end{array}$ & $\begin{array}{l}-.1240 \\
(.0174) \\
-.0349 *\end{array}$ & $\begin{array}{l}-.1889 \\
(.0087) \\
-.0555^{*}\end{array}$ \\
\hline Education $<9$ & $\begin{array}{l}-.3345 \\
(.0362) \\
-.1004 *\end{array}$ & $\begin{array}{l}-.2253 \\
(.0496) \\
-.0653 *\end{array}$ & $\begin{array}{c}.1704 \\
(.0486) \\
.0316^{*}\end{array}$ & $\begin{array}{c}.0505 \\
(.0293) \\
.0179 *\end{array}$ & $\begin{array}{l}-.3665 \\
(.0285) \\
-.1089 *\end{array}$ & $\begin{array}{l}-.3071 \\
(.0245) \\
-.0920^{*}\end{array}$ \\
\hline $9 \leq$ Education $<12$ & $\begin{array}{l}-.6436 \\
(.0307) \\
-.2059 *\end{array}$ & $\begin{array}{l}-.3062 \\
(.0350) \\
-.0900 *\end{array}$ & $\begin{array}{c}.0236 \\
(.0287) \\
.0046^{*}\end{array}$ & $\begin{array}{l}-.2683 \\
(.0239) \\
-.0959 *\end{array}$ & $\begin{array}{l}-.5488 \\
(.0218) \\
-.1694 *\end{array}$ & $\begin{array}{l}-.4739 \\
(.0179) \\
-.1469 *\end{array}$ \\
\hline Education $=12$ & $\begin{array}{l}-.1545 \\
(.0207) \\
-.0438 *\end{array}$ & $\begin{array}{l}-.0595 \\
(.0270) \\
-.0164 *\end{array}$ & $\begin{array}{c}.0216 \\
(.0143) \\
.0043 *\end{array}$ & $\begin{array}{l}-.0105 \\
(.0191) \\
-.0037 *\end{array}$ & $\begin{array}{l}-.0997 \\
(.0129) \\
-.0272 *\end{array}$ & $\begin{array}{l}-.0885 \\
(.0113) \\
-.0248^{*}\end{array}$ \\
\hline
\end{tabular}

(table continues) 
TABLE 6, continued

\begin{tabular}{|c|c|c|c|c|c|c|}
\hline & $\begin{array}{c}\text { (1) } \\
\text { High AFDC- } \\
\text { Benefit States }\end{array}$ & $\begin{array}{c}\text { (2) } \\
\text { Low AFDC } \\
\text { Benefit States }\end{array}$ & $\begin{array}{c}(3) \\
\text { With Private } \\
\text { Insurance }\end{array}$ & $\begin{array}{c}(4) \\
\text { Without } \\
\text { Private } \\
\text { Insurance }\end{array}$ & $\begin{array}{c}\text { Mother Age } \\
30 \text { and Above }\end{array}$ & $\begin{array}{c}\text { (6) } \\
\text { Exclude } \\
\text { Infants } \\
\end{array}$ \\
\hline Central city & $\begin{array}{l}-.3715 \\
(.0220) \\
-.1106^{*}\end{array}$ & $\begin{array}{l}-.2063 \\
(.0308) \\
-.0591 *\end{array}$ & $\begin{array}{l}-.2274 \\
(.0164) \\
-.0482 *\end{array}$ & $\begin{array}{l}-.2184 \\
(.0191) \\
-.0782 *\end{array}$ & $\begin{array}{l}-.3277 \\
(.0149) \\
-.0954 *\end{array}$ & $\begin{array}{l}-.3102 \\
(.0134) \\
-.0921^{*}\end{array}$ \\
\hline $\begin{array}{l}\text { Number of children } \\
\text { between } 0 \text { and } 5\end{array}$ & $\begin{array}{c}.1288 \\
(.0211) \\
.0349 *\end{array}$ & $\begin{array}{c}.0152 \\
(.0314) \\
.0041 *\end{array}$ & $\begin{array}{c}.3021 \\
(.0226) \\
.0522^{*}\end{array}$ & $\begin{array}{c}.1135 \\
(.0167) \\
.0400 *\end{array}$ & $\begin{array}{c}.1784 \\
(.0191) \\
.0458 *\end{array}$ & $\begin{array}{l}.1186 \\
(.0148) \\
.0320^{*}\end{array}$ \\
\hline $\begin{array}{l}\text { Number of children } \\
\text { between } 6 \text { and } 17\end{array}$ & $\begin{array}{c}.0948 \\
(.0138) \\
.0259 *\end{array}$ & $\begin{array}{c}.0728 \\
(.0175) \\
.0196^{*}\end{array}$ & $\begin{array}{c}.2521 \\
(.0105) \\
.0446^{*}\end{array}$ & $\begin{array}{c}.0857 \\
(.0100) \\
.0303 *\end{array}$ & $\begin{array}{c}.1303 \\
(.0075) \\
.0340^{*}\end{array}$ & $\begin{array}{c}.1276 \\
(.0072) \\
.0344^{*}\end{array}$ \\
\hline $\mathrm{N}$ & 28,274 & 16,842 & 71,083 & 32,076 & 73,425 & 91,517 \\
\hline $\begin{array}{l}\text { Mean of dependent } \\
\text { variable }\end{array}$ & 0.7238 & 0.7345 & 0.8635 & 0.4790 & 0.7838 & 0.7394 \\
\hline Pseudo $\mathrm{R}^{2}$ & .1504 & .1508 & .1318 & .1349 & .1198 & .1434 \\
\hline
\end{tabular}

Notes: Columns each from separate regression. Estimates from CPS, 1989-1994. Huber standard errors in parentheses. Controls for STATE*TIME and YOUNGEST*TIME interactions and a constant term. All models correct for intercorrelations within each state-time-youngest cell. Probability derivatives are marked with an asterisk. 
health insurance coverage and one-third did not. ${ }^{33}$ Columns (3) and (4) of Table 6 (which contain the same independent variables as in the baseline model) show that the coefficient on ALLELIG increases from 1.7 to 3.4 percentage points for those without private health insurance. On the other hand, covering all children in a family has an insignificant effect on families with employer-provided health insurance, with a probability derivative of 0.1 percentage points.

A second important issue is that women might react to the expansions by having additional children. If this is so, the effect of Medicaid that I observe in the data may not be a "marriage effect" but rather a "fertility effect." ${ }^{34}$ Although Ellwood and Bane (1985) and many subsequent studies find no evidence that higher cash benefits cause additional children, it remains important to examine this potential source of selection bias. To illustrate, consider a married couple without any children who react to the expansions by having a baby and enrolling the child in Medicaid. The family will then enter into my sample, and appear as if they are becoming married in response to the expansions, when they are not. ${ }^{35}$

I address the childbearing issue in two ways. As Ellwood and Bane (1985) note, childbearing varies substantially by a woman's age. Fertility data from Vital Statistics bear this out. Fertility rates (number of births per thousand women) decline dramatically after age 30. Relative to women aged 25 to 29, births fall by 35 percent for women aged 30 to 34 , and by 75 percent for women aged 35 to $39 .{ }^{36}$ To examine whether the expansions are an avenue to marriage, column (5) of Table 6 examines women aged

\footnotetext{
${ }^{33}$ Private health insurance coverage is derived from the CPS question "Was . . covered by private health insurance plan?"

${ }^{34}$ Schultz (1994) examines the interrelationship between marriage, fertility, and welfare benefits. He finds that both AFDC and Medicaid have negative effects that are sometimes statistically significant. However, in quantitative terms, there appears to be little effect of welfare on either marriage propensities or fertility. Yelowitz (1994) also examines Medicaid and fertility, and finds extremely weak effects.

${ }^{35}$ The effect of childbearing will not necessarily bias the coefficient on marriage upward, however. If a newly eligible single woman responds to the Medicaid expansions by having her first child, the coefficient would be biased downward.

${ }^{36}$ Although the distribution of a mother's age based on when her first child was born is more appropriate (because having a child is a qualifying characteristic), I was not able to locate such data.
} 
30 and above, who are far less likely to enter the sample from having a child. This specification shows Medicaid increases in the probability of marriage by 1.6 percentage points, somewhat smaller than the baseline specification. This estimate would suggest that roughly 10 percent of the effect that I attribute to marriage in the baseline specification could be due to increased childbearing. As a second check, column (6) excludes infants. The results from this column show a smaller effect than the previous column, though the economic importance of Medicaid on marriage still remains. Extending Medicaid is now associated with an increase in the probability of marriage of 1.1 percentage points. Overall, these two columns suggest that previous results may be overstated because of selection into the sample through childbearing, but the conclusion that Medicaid encourages marriage still holds.

A final issue is that my main model does not include any income measure, which I argue is endogenous. By excluding income, my study follows methods similar to other reduced-form studies that examine AFDC cash benefits (e.g., Moffitt 1994). Although the effect of income on marriage is itself interesting, the fundamental issue in the context of the Medicaid expansions is whether the Medicaid variable is correlated with omitted income after including other covariates (such as state, year, and child's age dummies), therefore resulting in omitted variables bias. Although intuition suggests that the "treatment" and "control" groups are similar in many other respects (including the distributions of income), it is important to address this concern directly.

Before saying what I did to address this concern, I should reiterate why income is endogenous. In related work (Yelowitz 1995), I have shown these same Medicaid expansions affected the work and welfare choices for single mothers-thus labor and transfer income seem particularly suspect to include on the right-hand side. Nonlabor, nontransfer income is certainly less controversial to use than labor or transfer income, but arguments can still be made that it is endogenous.

With that in mind, I took four steps to check the sensitivity and robustness of the results to the inclusion of income. The results are in Appendix Table 1 and 2 and correspond to the model in Table 4, 
column 1. First, I include nonlabor, nontransfer income directly in the marriage model. This income variable has a significant, negative effect on the marriage decision. More importantly for the purposes of my study, however, the effect of Medicaid eligibility still persists and is of similar magnitude to the model without income. This suggests that omitted income is not correlated with the ALLELIG variable (after including state, time, and child's age fixed effects). Second, I included predicted nonlabor, nontransfer income into the marriage model, given the concerns about its endogeneity. Columns (2) and (3) replace actual nonlabor, nontransfer income with its predicted value, using the OLS in column (2) to predict income and a probit in column (3) to predict marriage. Nonlabor, nontransfer income is predicted based on exogenous covariates - race, ethnicity, age, education, and central city residence. Again, the coefficient estimates in column (3) remain similar to the baseline specification. Third, I divided the sample into two groups, based on whether their total income was greater than 300 percent of the poverty line. This is meant to be a specification check, however, rather than an attempt to address concerns about the endogeneity of income. The expansions should not have much effect on wealthy individuals. This expectation is borne out in column (5)—Medicaid eligibility has no effect on marriage. On the other hand, significant effects persist in column (4), which includes women with total income less than 300 percent of the poverty line.

Finally, I modeled the (marriage, income) decision jointly, using a multinomial logit. I model the joint outcome as four different categories: married or unmarried, and low or high income (where I use a cutoff of 150 percent of the poverty line). The Medicaid expansions generally allowed single mothers to (a) increase their total income and (b) get married. Hence, mothers should have moved from the (unmarried, low income) cell into (unmarried, high income) and (married, high income) cells. Appendix Table 2 presents the results. Relative to the omitted category (unmarried, low income), the Medicaid expansions caused women to shift into the (unmarried, high income) and (married, high income) categories. This first finding is consistent with previous findings on single women (Yelowitz 1995). The expansions did not cause women to shift into the (married, low income) group, however. 


\section{CONCLUDING REMARKS}

In this paper, I have attempted to fill a gap in the literature by examining the influence of Medicaid on marriage. This paper has shown that extending Medicaid to all children in a family has a strong impact on the marriage decision, which stands in contrast to previous work on AFDC cash benefits. Using an exogenous source of variation to the mother's budget set and a large, representative sample, I estimate that extending Medicaid to all children in a family increases the probability of marriage by 1.7 percentage points. This finding is robust to the inclusion of state fixed effects. The magnitude of Medicaid also changes in sensible ways when the model addressed concerns about private health insurance and selection bias from changes in a mother's fertility. The estimates strongly show nonlinear effects of Medicaid coverage. The impact on marriage is concentrated in covering the last child in a household.

Previous work finds smaller effects of cash benefits on the female headship. Why does Medicaid matter while cash does not? There are several ways in which these findings can be reconciled. First, the potential husband may be less able to substitute employer-provided health insurance for Medicaid than wages for AFDC cash benefits. Second, the effect of welfare benefits on the decision to marry and the decision to divorce may be asymmetric. If negative connotations are associated with the latter, through some kind of "divorce stigma," then welfare benefits may not have as much impact. Third, Medicaid may be more highly valued than a small cash grant. Medicaid is kept in its entirety when on AFDC, whereas cash benefits are taxed away. Finally, if the stigma associated with Medicaid participation is smaller than the stigma associated with AFDC participation, then changing Medicaid policy could lead to greater responsiveness than changing AFDC policy. 


\section{APPENDIX 1: Legislative Changes in the 1980s}

Sixth Omnibus Budget Reconciliation Act, 1986 (SOBRA 86): Permitted states to extend Medicaid coverage to children under age 2 with incomes below 100 percent of the FPL effective April 1987. Beginning July 1988, states could increase the age level by one in each fiscal year until all children under age 5 were included.

Omnibus Budget Reconciliation Act, 1987 (OBRA 1987): Effective July 1988, states could immediately cover children under age 5 (rather than phasing in coverage) who were born after September 1983. Effective October 1988, states can expand coverage to children under age 8. Allowed states to extend Medicaid eligibility for infants up to 185 percent of the FPL.

Medicare Catastrophic Coverage Act, 1988 (MCCA 88): Required states to cover infants on a phased-in schedule: to 75 percent of the FPL, effective July 1989, and to 100 percent, effective July 1990.

Family Support Act, 1988 (FSA 88): Effective April 1990, required states to continue Medicaid coverage for twelve months for families who received AFDC in three of the previous six months, but became ineligible for assistance because of increased earnings. Families whose incomes exceeded 185 percent of the FPL would not qualify. Families with incomes between 100 and 185 percent of the poverty guidelines could be charged a premium during the second six months.

Omnibus Budget Reconciliation Act, 1989 (OBRA 89): Required states to extend Medicaid coverage to all children under age 6 with family incomes up to 133 percent of the FPL. Effective April 1990.

Omnibus Budget Reconciliation Act, 1990 (OBRA 90): Starting July 1991, states are required to cover all children under age 19 who were born after September 1983, to 100 percent of the FPL.

Source: Yelowitz (1995). 
APPENDIX TABLE 1

Robustness of ALLELIG to the Inclusion of Different Income Measures

\begin{tabular}{|c|c|c|c|c|c|}
\hline & $\begin{array}{c}(1) \\
\text { Include } \\
\mathrm{Y}_{\mathrm{NLNT}} \\
\end{array}$ & $\begin{array}{c}(2) \\
\text { Outcome = } \\
\text { Predicted } \\
\mathrm{Y}_{\mathrm{NLNT}} \\
\end{array}$ & $\begin{array}{c}(3) \\
\text { Include } \\
\text { Predicted } \\
\mathrm{Y}_{\mathrm{NLNT}} \\
\end{array}$ & $\begin{array}{l}\quad(4) \\
\text { Total Income } \\
<300 \% \text { FPL } \\
\end{array}$ & $\begin{array}{c}(5) \\
\text { Total Income } \\
\geq 300 \% \text { FPL } \\
\end{array}$ \\
\hline All children eligible & $\begin{array}{c}.0479 \\
(.0141)\end{array}$ & - & $\begin{array}{c}.0477 \\
(.0141)\end{array}$ & $\begin{array}{l}.0382 \\
(.0168)\end{array}$ & $\begin{array}{l}-.0071 \\
(.0313)\end{array}$ \\
\hline Black & $\begin{array}{r}-1.0852 \\
(.0144)\end{array}$ & $\begin{array}{r}-851.76 \\
(70.54)\end{array}$ & $\begin{array}{r}-1.6686 \\
(.0284)\end{array}$ & $\begin{array}{r}-1.0551 \\
(.0171)\end{array}$ & $\begin{array}{l}-.6987 \\
(.0334)\end{array}$ \\
\hline Other nonwhite & $\begin{array}{l}-.0582 \\
(.0222)\end{array}$ & $\begin{array}{c}248.35 \\
(101.54)\end{array}$ & $\begin{array}{l}.1137 \\
(.0234)\end{array}$ & $\begin{array}{l}-.0524 \\
(.0260)\end{array}$ & $\begin{array}{l}.1483 \\
(.0525)\end{array}$ \\
\hline Hispanic & $\begin{array}{l}-.0067 \\
(.0192)\end{array}$ & $\begin{array}{r}-696.17 \\
(83.16)\end{array}$ & $\begin{array}{l}-.4835 \\
(.0277)\end{array}$ & $\begin{array}{l}.0842 \\
(.0216)\end{array}$ & $\begin{array}{l}-.0878 \\
(.0503)\end{array}$ \\
\hline Mother's age & $\begin{array}{l}.1750 \\
(.0052)\end{array}$ & $\begin{array}{r}-166.70 \\
(23.71)\end{array}$ & $\begin{array}{c}.0607 \\
(.0028)\end{array}$ & $\begin{array}{l}.1058 \\
(.0062)\end{array}$ & $\begin{array}{c}.2687 \\
(.0119)\end{array}$ \\
\hline $\mathrm{Age}^{2} / 100$ & $\begin{array}{l}-.1908 \\
(.0074)\end{array}$ & $\begin{array}{l}464.66 \\
(34.18)\end{array}$ & $\begin{array}{l}.1278 \\
(.0086)\end{array}$ & $\begin{array}{l}-.1100 \\
(.0089)\end{array}$ & $\begin{array}{l}-.3228 \\
(.0162)\end{array}$ \\
\hline Education $<9$ & $\begin{array}{l}-.3325 \\
(.0218)\end{array}$ & $\begin{array}{r}-1628.50 \\
(108.01)\end{array}$ & $\begin{array}{r}-1.4479 \\
(.0503)\end{array}$ & $\begin{array}{l}-.0000 \\
(.0236)\end{array}$ & $\begin{array}{c}.2753 \\
(.1101)\end{array}$ \\
\hline $9 \leq$ Education $<12$ & $\begin{array}{l}-.5243 \\
(.0157)\end{array}$ & $\begin{array}{r}-1179.79 \\
(78.17)\end{array}$ & $\begin{array}{r}-1.3323 \\
(.0350)\end{array}$ & $\begin{array}{l}-.2664 \\
(.0176)\end{array}$ & $\begin{array}{c}.1187 \\
(.0559)\end{array}$ \\
\hline Education $=12$ & $\begin{array}{l}-.1150 \\
(.0103)\end{array}$ & $\begin{array}{r}-1025.77 \\
(47.55)\end{array}$ & $\begin{array}{l}-.8179 \\
(.0302)\end{array}$ & $\begin{array}{l}.0698 \\
(.0129)\end{array}$ & $\begin{array}{l}.1577 \\
(.0216)\end{array}$ \\
\hline Central city & $\begin{array}{l}-.3099 \\
(.0115)\end{array}$ & $\begin{array}{c}58.42 \\
(53.65)\end{array}$ & $\begin{array}{l}-.2683 \\
(.0116)\end{array}$ & $\begin{array}{l}-.2979 \\
(.0138)\end{array}$ & $\begin{array}{l}-.1880 \\
(.0253)\end{array}$ \\
\hline $\begin{array}{l}\text { Number of children } \\
\text { between } 0 \text { and } 5\end{array}$ & $\begin{array}{l}.1077 \\
(.0117)\end{array}$ & - & $\begin{array}{l}.1070 \\
(.0117)\end{array}$ & $\begin{array}{l}.1762 \\
(.0128)\end{array}$ & $\begin{array}{l}.4018 \\
(.0424)\end{array}$ \\
\hline $\begin{array}{l}\text { Number of children } \\
\text { between } 6 \text { and } 17\end{array}$ & $\begin{array}{l}.1066 \\
(.0062)\end{array}$ & - & $\begin{array}{l}-.2683 \\
(.0116)\end{array}$ & $\begin{array}{l}.1725 \\
(.0071)\end{array}$ & $\begin{array}{l}.3857 \\
(.0181)\end{array}$ \\
\hline
\end{tabular}

(table continues) 
APPENDIX TABLE 1, continued

\begin{tabular}{|c|c|c|c|c|c|}
\hline & $\begin{array}{c}(1) \\
\text { Include } \\
\mathrm{Y}_{\mathrm{NLNT}} \\
\end{array}$ & $\begin{array}{c}(2) \\
\text { Outcome = } \\
\text { Predicted } \\
\mathrm{Y}_{\mathrm{NLNT}} \\
\end{array}$ & $\begin{array}{c}(3) \\
\text { Include } \\
\text { Predicted } \\
\mathrm{Y}_{\mathrm{NLNT}} \\
\end{array}$ & $\begin{array}{l}\text { Total Income } \\
<300 \% \text { FPL } \\
\end{array}$ & $\begin{array}{l}\text { Total Income } \\
\geq 300 \% \text { FPL } \\
\end{array}$ \\
\hline $\begin{array}{l}\text { Nonlabor, nontransfer } \\
\text { income/10,000 }\end{array}$ & $\begin{array}{l}-.0578 \\
(.0063)\end{array}$ & - & - & - & - \\
\hline $\begin{array}{l}\text { Predicted nonlabor, } \\
\text { nontransfer } \\
\text { income } / 10,000\end{array}$ & - & - & $\begin{array}{l}-.0692 \\
(.0029)\end{array}$ & - & - \\
\hline
\end{tabular}

Notes: Columns 1, 3, 4, and 5 run as probit model; column 2 as OLS. Columns each from separate regression. Estimates from CPS, 1989-1994. Controls for STATE, TIME, and YOUNGEST interactions and a constant term. Standard errors in parentheses. Models correspond to Table 4, column (1). $\mathrm{Y}_{\mathrm{NLNT}}$ stands for nonlabor, nontransfer income. 
APPENDIX TABLE 2

Multinomial Logit Jointly Modeling (Married or Unmarried, High or Low Income)

(1) Unmarried, High Income
(2)

(3)

\begin{tabular}{|c|c|c|c|}
\hline & Unmarried, High Income & Married, Low Income & Married, High Income \\
\hline All children eligible & $\begin{array}{l}.1174 \\
(.0425)\end{array}$ & $\begin{array}{l}.0468 \\
(.0377)\end{array}$ & $\begin{array}{c}1269 \\
.(.0312)\end{array}$ \\
\hline Black & $\begin{array}{l}-.6658 \\
(.0362)\end{array}$ & $\begin{array}{l}-1.5960 \\
(.0401)\end{array}$ & $\begin{array}{l}-2.1517 \\
(.0302)\end{array}$ \\
\hline Other nonwhite & $\begin{array}{l}-.5151 \\
(.0708)\end{array}$ & $\begin{array}{c}.0584 \\
(.0557)\end{array}$ & $\begin{array}{l}-.4069 \\
(.0485)\end{array}$ \\
\hline Hispanic & $\begin{array}{l}-.1284 \\
(.0595)\end{array}$ & $\begin{array}{l}.3220 \\
(.0459)\end{array}$ & $\begin{array}{l}-.2511 \\
(.0421)\end{array}$ \\
\hline Mother's age & $\begin{array}{l}.0981 \\
(.0150)\end{array}$ & $\begin{array}{l}.0728 \\
(.0135)\end{array}$ & $\begin{array}{l}.4283 \\
(.0117)\end{array}$ \\
\hline Mother's age ${ }^{2} / 100$ & $\begin{array}{l}-.1019 \\
(.0212)\end{array}$ & $\begin{array}{l}-.0398 \\
(.0195)\end{array}$ & $\begin{array}{l}-.4772 \\
(.0168)\end{array}$ \\
\hline Education $<9$ & $\begin{array}{r}-2.4362 \\
(.0848)\end{array}$ & $\begin{array}{l}.3182 \\
(.0490)\end{array}$ & $\begin{array}{l}-2.0399 \\
(.0469)\end{array}$ \\
\hline $9 \leq$ Education $<12$ & $\begin{array}{l}-1.9779 \\
(.0497)\end{array}$ & $\begin{array}{l}-.1971 \\
(.0393)\end{array}$ & $\begin{array}{l}-1.9675 \\
(.0334)\end{array}$ \\
\hline Education $=12$ & $\begin{array}{l}-.8238 \\
(.0306)\end{array}$ & $\begin{array}{l}.1601 \\
(.0319)\end{array}$ & $\begin{array}{l}-.7035 \\
(.0242)\end{array}$ \\
\hline Central city & $\begin{array}{l}-.2762 \\
(.0328)\end{array}$ & $\begin{array}{l}-.4606 \\
(.0306)\end{array}$ & $\begin{array}{l}-.6748 \\
(.0249)\end{array}$ \\
\hline $\begin{array}{l}\text { Number of children } \\
\text { between } 0 \text { and } 5\end{array}$ & $\begin{array}{l}-1.0950 \\
(.0493)\end{array}$ & $\begin{array}{l}.3392 \\
(.0258)\end{array}$ & $\begin{array}{l}-.3006 \\
(.0247)\end{array}$ \\
\hline $\begin{array}{l}\text { Number of children } \\
\text { between } 6 \text { and } 17\end{array}$ & $\begin{array}{l}-.7836 \\
(.0215)\end{array}$ & $\begin{array}{c}.2936 \\
(.0152)\end{array}$ & $\begin{array}{l}-.1964 \\
(.0135)\end{array}$ \\
\hline
\end{tabular}

Notes: Estimates from CPS, 1989-1994. Also controls for STATE, TIME, and YOUNGEST interactions and a constant term. Standard errors in parentheses. High income defined as total income greater than or equal to 150 percent of FPL. Includes same variables as Table 4, column (1). 


\section{References}

Blank, R. 1989. "The Effect of Medical Need and Medicaid on AFDC Participation." Journal of Human Resources 24(1): 54-87.

Cain, G. G., and D. A. Wissoker. 1990. "A Reanalysis of Marital Stability in the Seattle-Denver IncomeMaintenance Experiment.” American Journal of Sociology 95(5): 1235-69.

Currie, J., and J. Gruber. 1994. "Saving Babies: The Efficacy and Cost of Recent Expansions of Medicaid Eligibility for Pregnant Women.” NBER Working Paper No. 4644.

Currie, J., and J. Gruber. 1996. "Health Insurance Eligibility, Utilization of Medical Care, and Child Health." Quarterly Journal of Economics 111(2): 431-66.

Cutler, D., and J. Gruber. 1996. “Does Public Insurance Crowd Out Private Insurance?” Quarterly Journal of Economics 111(2): 391-430.

Danziger, S., G. Jakubson, S. Schwartz, and E. Smolensky. 1982. "Work and Welfare as Determinants of Female Poverty and Household Headship.” Quarterly Journal of Economics 97(3): 519-34.

Decker, S. 1995. “Medicaid, AFDC and Female Headship.” Mimeo, New York University.

Duncan, G., and S. Hoffman. 1990. "Welfare Benefits, Economic Opportunities, and Out-of-Wedlock Births among Black Teenage Girls.” Demography 27(4): 519-35.

Ellwood, D. T., and M. J. Bane. 1985. "The Impact of AFDC on Family Structure and Living Arrangements." In Research in Labor Economics vol. 7, ed. R. Ehrenberg, pp. 137-207. Greenwich, Conn.: JAI Press.

Groeneveld, L., M. Hannan, and N. Tuma. 1980. "The Effects of Negative Income Tax Programs on Marital Dissolution.” Journal of Human Resources 15(4): 654-74.

Hannan, M., and N. Tuma. 1990. "A Reassessment of the Effect of Income Maintenance on Marital Dissolution in the Seattle-Denver Experiment.” American Journal of Sociology 95(5): 1270-98.

Hoffman, S. D., and G. J. Duncan. 1988. "A Comparison of Choice-Based Multinomial and Nested Logit Models: The Family Structure and Welfare Use Decisions of Divorced or Separated Women." Journal of Human Resources 23(4): 550-62.

Hoynes, H. 1993. "Female Headship and AFDC Benefits: State Effects or Welfare Effects?" Mimeo, University of California, Berkeley.

Hoynes, H. 1996. "Welfare Transfers in Two Parent Families: Labor Supply and Welfare Participation Under AFDC-UP.” Econometrica 64(2): 295-332.

Hutchens, R., G. Jakubson, and S. Schwartz. 1989. "AFDC and the Formation of Subfamilies.” Journal of Human Resources 24(4): 599-628. 
Intergovernmental Health Policy Project. "Major Changes in State Medicaid and Indigent Care Programs." Eds. Debra J. Lipson, Rhona S. Fisher and Constance Thomas. Various issues. The George Washington University.

Lundberg, S., and R. Plotnick. 1995. “Adolescent Premarital Childbearing: Do Economic Incentives Matter?” Journal of Labor Economics 13(2): 177-200.

Moffitt, R. 1990. "The Effect of the U.S. Welfare System on Marital Status," Journal of Public Economics 41(1): 101-24.

Moffitt, R. 1992. "Incentive Effects of the U.S. Welfare System: A Review." Journal of Economic Literature 30(1): 1-61.

Moffitt, R. 1994. "Welfare Effects on Female Headship with Area Effects." Journal of Human Resources 29(2): 621-36.

Moffitt, R., R. Reville, and A. Winkler. 1994. "State AFDC Rules Regarding the Treatment of Cohabitors: 1993.” Social Security Bulletin 57(4): 26-33.

Moffitt, R., R. Reville, and A. Winkler. 1995. "State AFDC Rules Regarding the Treatment of Cohabitors: 1993.” IRP Discussion Paper.

Moffitt, R., and B. Wolfe. 1992. "The Effect of the Medicaid Program on Welfare Participation and Labor Supply." Review of Economics and Statistics 74(4): 615-26.

Moulton, B. R. 1986. "Random Group Effects and the Precision of Regression Estimates," Journal of Econometrics 32(3): 385-97.

Plotnick, R. 1983. "Turnover in the AFDC Population: An Event History Analysis." Journal of Human Resources 18(1): 65-81.

Plotnick, R. 1990. "Welfare and Out-of-Wedlock Childbearing: Evidence from the 1980s." Journal of Marriage and the Family 52(August): 735-46.

Scholz, J. K. 1994. “Tax Policy and the Working Poor: The Earned Income Tax Credit.” Focus 15(3): 1-12.

Schultz, T. P. 1994. "Marital Status and Fertility in the United States: Welfare and Labor Market Effects." Journal of Human Resources 29(2): 637-69.

Shore-Sheppard, L. D. 1995. "Stemming the Tide? The Effect of Expanding Medicaid Eligibility on Health Insurance Coverage." Mimeo, Princeton University.

U.S. Department of Health and Human Services, Vital Statistics of the United States: Natality. 1988.

U.S. House of Representatives. 1993. Medicaid Source Book: Background Data and Analysis (A 1993 Update). Washington D.C.: U.S. Government Printing Office. 
U.S. House of Representatives. Various years. Background Materials and Data on Programs within the Jurisdiction of the Committee on Ways and Means. Washington D.C.: U.S. Government Printing Office.

Walker, J. R. 1994. "Migration among Low-Income Households: Helping the Witch Doctors Reach Consensus." IRP Discussion Paper no. 1031.

Winkler, A. 1991. "The Incentive Effect of Medicaid on Women's Labor Supply." Journal of Human Resources 26(2): 308-37.

Winkler, A. 1995. "Does AFDC-UP Encourage Two-Parent Families?" Journal of Policy Analysis and Management 14(1): 4-24.

Yelowitz, A. 1994. “Is Health Insurance Coverage a Pro-natal Policy?'Mimeo, University of California, Los Angeles.

Yelowitz, A. 1995. "The Medicaid Notch, Labor Supply and Welfare Participation: Evidence from Eligibility Expansions." Quarterly Journal of Economics 110(4): 909-40. 